\title{
Deciphering the genetics of pig complex traits through QTL mapping and positional candidate cloning
}

\author{
Dissertation \\ to obtain the $\mathrm{Ph}$. D. degree \\ in the Faculty of Agricultural Sciences, \\ Georg-August-University Göttingen, Germany \\ presented by \\ Nengshui Ding \\ born in Jiangxi, P.R.China
}

Göttingen, December, 2006 
D7

1. Name of referee: Prof. Dr. Dr. Bertram Brenig

2. Name of co-referee: Prof. Dr. Christoph Knorr

Date of dissertation: 1th February, 2007 
Dedicated $\mathscr{T}_{0} \mathscr{M}_{y}$ Defoved $\mathfrak{F}_{\text {amily... }}$ 


\section{Table of Contents}

List of Publications.....................................................

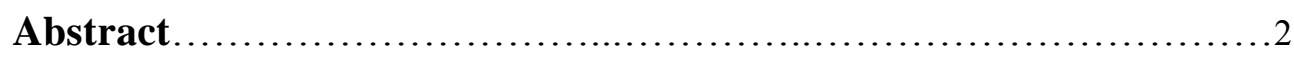

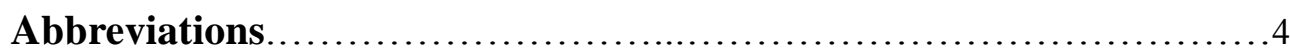

List of Figures.................................................6

List of Tables.......................................................

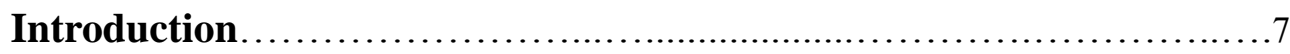

1 Strategies for dissecting complex traits..................................

1.1 QTL Mapping....................................................

1.2 From QTL to QTN....................................................... 10

2 Pig teat number................................................................

2.1 Inheritance of teat number.............................................12

2.2 QTLs for teat number............................................. 13

3 Pig Inguinal $/$ scrotal hernia...............................................

3.1 Epidemiology and Inheritance of Pig Scrotal/Inguinal Hernia..............15

3.2 Etiology of Inguinal/scrotal hernia..................................16

3.2.1 Obliteration of processus vaginalis........................... 16

3.2.2 Testicular descent............................................. 19

3.2.3 Collagen hypothesis.......................................22

3.3 Molecular progress for hernia Inguinalis/scrotalis in pig..................25

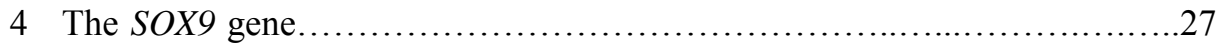

4.1 Biological/physiological function of SOX9 .......................27

4.1.1 Function in the development of male gonad...................27

4.1.2 Function in the collagen metabolism.........................................29

4.1.3 Function in apoptosis........................................ 30

4.2 Molecular structure and features of the SOX9 gene.....................30

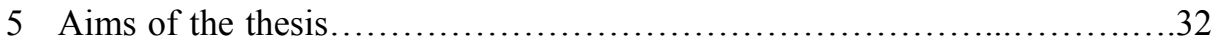

References............................................................

Acknowledgements.............................................46

Curriculum Vitae..................................................47 


\section{List of Publications}

The present dissertation is based on the following publications:

1. Knorr C, Beck J, Beuermann C, Chen K, Ding N, Gatphayak K, Huang LS, Laenoi W and Brenig B. (2006) Chromosomal assignment of porcine oncogenic and apoptopic genes CACNA2D2, TUSC4, ATP2A1, COL1A1, TAC1, BAK1 and CASP9. Anim Genet, 5, 523-525.

2. Ding NS, Guo YM, Knorr C, Ma JW, Lan LT, Ai HS, Haley CS, Brenig B and Huang LS (2006) Genome-wide QTL mapping for teat number in an Erhualian $\times$ White Duroc pig resource population. BMC Genetics (submitted).

3. Ding NS, Knorr C, Baumgartner BG, Beck J, Huang LS and Brenig B (2007) Molecular characterization and evaluation of the porcine SOX9 gene as a positional candidate for inguinal/scrotal hernia. In preparation. 


\section{Abstract}

Most traits in livestock are controlled by multiple genes and are therefore called genetically complex traits. Emerging genetic resources and technologies, genomic strategies, enable the systematic identification of quantitative trait loci (QTLs), quantitative trait genes (QTGs) and quantitative trait nucleotides (QTNs) underlying these complex traits.

In this thesis, we firstly report the molecular characterization and evaluation of the porcine $S O X 9$ gene as a positional candidate for inguinal/scrotal hernia. The SOX9 gene was assigned to SSC12p13-p14 by FISH and RH-panel analysis. The genomic DNA sequence of 11,330 bp containing the whole SOX9 gene was sequenced. Four polymorphisms (SNP-5'UTR-G-420A, SNP-5'UTR-G195T, an $18 \mathrm{bp}$ deletion at $223 \mathrm{bp}$ of the 5'UTR and SNP-intron2-G2462T) were detected and genotyped. Association analyses between the SOX9 gene and pig hernia inguinalis/scrotalis were performed with HaploView software. The results showed that the 18-bp deletion had a significant effect on hernia inguinalis/scrotalis in pig $(\mathrm{p}<0.05)$. Subsequently, a protein factor binding specifically to the 18-bp-deletion allele was detected using electrophoretic mobility shift assay (EMSA). Further transfection assays showed that the deletion leads to a dramatic increase in the transcription activation compared to the insertion. We propose that this deletion creates a potential binding site of a transcription factor to enhance SOX9 expression level which might contribute to pig inguinalis/scrotalis through its functions on the development of the male gonad, collagen metabolism and apoptosis.

In the present thesis, we also performed a genome-wide scan to identify quantitative trait loci (QTLs) affecting the traits associated with teat number. A 
total of 151 microsatellites evenly distributed over 18 porcine autosomes and the $\mathrm{X}$-chromosome were genotyped for $560 \mathrm{~F}_{2}$ pigs in a White Duroc $\times$ Erhualian intercross. A linkage map with a total length of $2471.4 \mathrm{cM}$ and the average marker interval of $19.3 \mathrm{cM}$ was produced. Linear regression method was used to map QTL via QTL Express. Four genome-wide significant QTLs for total teat number (TTN) were detected on SSC4 $(p<0.05), \operatorname{SSC} 7(p<0.01), \operatorname{SS} 12(p<0.01)$ and SSC13 $(\mathrm{p}<0.05)$. Four chromosomal regions prominently affecting the teat number of right side $(\mathrm{RTN})$ were identified on SSC3 $(\mathrm{p}<0.01)$, SS7 $(\mathrm{p}<0.001)$, SSC12 $(\mathrm{p}<0.01)$ and SSC15 $(\mathrm{p}<0.01)$, while only two significant QTLs related to left teat number (LTN) were found on SSC7 $(p<0.01)$ and SSC12 $(p<0.05)$. The estimated additive effects indicated that Erhualian alleles at the most significant QTLs had positive additive effects compared with the Duroc alleles, except for one QTL on SSC7 at which White Duroc alleles showed increasing teat numbers. Imprinting effects on TTN were detected on SSC7 and SSC12. The study appears to be the first presentation of QTLs for left and right side teat number in pigs. 


\section{Abbreviations}

\begin{tabular}{|c|c|}
\hline ABCG2 & ATP binding cassette sub family $G$ member 2 \\
\hline AI & Artificial insemination \\
\hline $\mathrm{AMH}$ & Anti- Müllerian hormone \\
\hline ASP & Affected sib pairs \\
\hline BLUP & Best Linear Unbiased Prediction \\
\hline bp & Base pair \\
\hline CALCA & CALC(Calcitonin)-A/ $\alpha-C G R P$ \\
\hline CEA & Carcinoembryonic antigen \\
\hline CEACAM1 & Carcinoembryonic antigen-related cell adhesion molecule 1 \\
\hline CREB & cAMP-response element-binding protein \\
\hline Col2 $\alpha 1$ & Collagen $\alpha 1$ (II) \\
\hline Col11 $\alpha 2$ & Collagen $\alpha 2(\mathrm{XI})$ \\
\hline $\operatorname{Col} 27 \alpha 1$ & Collagen $\alpha 1$ (XXVII) \\
\hline CSL & Cranial suspensory ligament \\
\hline CGRP & Calcitonin gene-related peptide \\
\hline DNA & Deoxyribonucleic acid \\
\hline DGAT1 & Diacylglycerol-acyltransferase 1 \\
\hline $\mathrm{dpc}$ & Days post coitum \\
\hline EBV & Estimated breeding value \\
\hline ELN & Elastin \\
\hline EMSA & Electrophoretic mobility shift assay \\
\hline FA & Fluctuating aysmmetry \\
\hline FISH & Fluorescence in situ hybridization \\
\hline GDF8 & Growth differentiation factor 8 (myostatin) \\
\hline GFN & Genitofemoral nerve \\
\hline GREAT/LGR8 & $\begin{array}{l}\text { G protein-coupled receptor affecting } \\
\text { descent/Relaxin receptor } 8\end{array}$ \\
\hline GUSB & $\beta$-glucuronidase \\
\hline IBD & Identical-by-descent \\
\hline IGF2 & Insulin-like growth factor 2 \\
\hline
\end{tabular}


INSL3

IP3

LD

LTN

MAS

MIS

MMPs

mRNA

PCD

PV

QTG

QTL

QTN

RLF

$\mathrm{RH}$

RTN

SF1

SNP

SOX9

SRY

SSC

TDT

TTN

UTR
Insulin-like peptide 3

Inositol 1,4,5-trisphosphate

Linkage disequilibrium

Left teat number

Marker-assisted selection

Müllerian inhibiting substance

Matrix metalloproteinases

Messenger Ribonucleic Acid

Programmed cell death

Processus vaginalis

Quantitative trait gene

Quantitative trait locus

Quantitative trait nucleotide

Relax-like factor

Radiation hybrid

Right teat number

Steroidogenic factor 1

Single nucleotide polymorphism

SRY-Related High-Mobility Group (HMG) Box 9

Sex-Determining Region on the Y Chromosome

Sus scrofa Chromosome

Transmission disequilibrium test

Total teat nuber

Untranslated region 


\section{List of Figures}

Figure 1: Approaches to mapping and positional cloning of QTLs in 11 domestic animals

Figure 2: Scheme of the development and obliteration of process vaginalis in the 17 descent of testes in human

Figure 3: The possible pathway of obliteration of processus vaginalis 19

Figure 4: Schematic illustration of the events involved in the descent of the 20 differentiating testis from a peri-renal to an inguinal position

Figure 5: Pathogenesis of hernia formation 25

Figure 6: Model for initiation of sex determination 28

\section{List of Tables}

Table 1: QTNs for complex traits have been identified in livestock 11

$\begin{array}{ll}\text { Table 2: } & \text { QTLs for teat number in pigs }\end{array}$

Table 3: Anatomical phases of testicular descent and their hormonal 21 control 


\section{Introduction}

The pig is among of the world's most important livestock because it not only provides the major red meat consumed (43\%) worldwide (Rothschild et al., 1998), but also serves as an important model for human health and represents a significant future source of organs for transplantation (Rothschild, 2003). It is well-known that most of the biological or economically important traits and the majority of common genetic diseases in pigs have a complex multifactorial inheritance. Yet, very little is known about the detailed molecular architecture of these traits, such as how many genes are involved, what is the distribution of gene effects, how important are gene-by-gene and gene-by-environment interaction, how important are epigenetic mechanisms, etc. So, the genetic dissection of complex traits is one of the most difficult and important challenges. With the advancements in pig genetics and genomics, this arduous mission becomes feasible (Womack, 2005).

\section{Strategies for dissecting complex traits}

To identify the QTGs (Quantitative Trait Genes) and QTNs (Quantitative Trait Nucleotides) underlying economically important traits and complex disorders such as hernia inguinalis/scrotalis in pig, the QTLs are localized by within family linkage analyses as the first step, then fine-mapped by exploiting population-wide linkage disequilibrium and ultimately characterized by genomic sequencing and functional validation assay.

\subsection{QTL Mapping}

The use of segregation analysis in informative families or experimental crosses to map QTLs has been well established (Lynch et al., 1998). The basic resources 
critical to QTL mapping are appropriate pedigreed populations with phenotype records and genomic DNA samples (Mehar et al., 2004). Designs for detecting QTL in livestock vary from experimental backcross and $F_{2}$ populations to half-sib designs that use existing family structures within a commercial breeding population. In comparison to plant species and laboratory animals, genome mapping in livestock faces the following challenges: 1) inbred lines are not commonly available, 2) maintenance of experimental populations can be prohibitively expensive, 3 ) reproductive capacity and generation interval are often limiting in the choice of experimental design (de Koning et al., 2003). These factors have to be taken into account in both the design and analysis of QTL experiments. Using a sparse marker map (10-20 cM marker interval), several designs have been used to detect quantitative trait loci (QTLs) across the genome in pig.

Experimental crosses: Experimental crosses have been often implemented in pigs because generation intervals are relatively short and the number of offspring is moderate to high. Such crosses have been commonly established between outbred lines with remarkable differences in performances to produce $F_{2}$ or backcross populations (Knott et al., 1998; Rohrer, 2000). In comparison to either single backcross, the $\mathrm{F}_{2}$ design is more powerful for detecting QTL with additive and dominance effects.

The QTL analysis model used in outbred crosses is largely the same as that used in the analysis of inbred crosses: marker alleles in the second generation are traced back to their line origin and contrasts for putative QTLs are estimated as differences between lines. Because crosses are between outbred lines, the analysis needs to accommodate the fact that founder lines may share alleles at the marker level. Because lines may not be fixed for alternate QTL alleles, these analyses estimate contrasts between average effects of QTL alleles derived from the 
parental breeds, which only represent estimates of the actual effects if alternative QTL alleles are fixed in the founder lines (Perez-Enciso et al., 2000). So the major disadvantage of outbred-line crosses is that the degree of homozygosity at marker loci is lower than that in inbred-line crosses which are hardly available in pigs, and then may decrease the power of QTL mapping. This model is straightforward to implement using least squares methodology and has been extended to accommodate more complex genetic models like imprinting, sex-linked and/or sex-specific QTL, and epistatic QTL interactions (Haley et al., 1994; Perez-Enciso et al., 2002; Carlborg et al., 2002). Most of these models have been implemented in a user-friendly free analysis package accessible via the web at http://qtl.cap.ed.ac.uk/.

Commercial breeding family: To map QTLs for complex diseases in pigs, experimental crosses are extremely difficult to develop because of low incidence, fertility malady, time consuming and high expenditure, e.g. anal atresia and pig hernia, although one experimental population has been successfully developed to map bovine umbilical hernia (Ron et al., 2004). So, a more common approach is to exploit the existing pedigrees with field data recording, especially those in artificial insemination (AI) stations and commercial populations. In these populations, genotypes and phenotypes are collected in a large number of half-sib offspring and their progenies or affected individuals and their unaffected relatives. Nonparametric approach based on identical-by-descent (IBD) allele sharing among affected individuals, and transmission/disequilibrium tests based on comparison of the number of times a marker allele is transmitted versus not-transmitted from a marker heterozygote parent to affected offspring, are often used to identify chromosomal regions associated with traits in this kind of populations. The half-sib design and affected sib pairs design have been successfully implemented in genome-wide QTL analysis of pig diseases 
(Grindflek et al., 2006; Knorr et al., 2006).

In total, the power of such analyses to detect and map QTLs depends on how large a fraction of the phenotypic variation is explained by a given locus and the type and size of the segregating population.

\subsection{From QTL to QTN}

The principal challenge for deciphering complex traits lies not in detecting QTLs, but in unraveling the genes responsible for these traits. To identify genes and mutations that underlie QTLs, the chromosomal region of a QTL is obtained from initial QTL mapping, its confidential interval is normally larger than $20 \mathrm{cM}$ and contains several hundred genes, and the region needs to be refined using high-resolution mapping approaches. To achieve this goal, additional markers are often to be developed and utilized for second-round scanning. A targeted, inexpensive and fast method to develop microsatellites from large-insert libraries had been introduced (Chen et al., 2005). Single nucleotide polymorphisms (SNPs) have also been developed quickly in farm animals. Furthermore, large-size family with some strategies is a powerful approach for fine mapping of QTLs. Multiple continuous generation in conventional backcrosses and $F_{2}$ intercrosses families and advanced intercross lines (AIL) which can generate more recombination events have been proved to be an effective potential way to narrow the QTL region significantly (Darvasi, 1998; Wang et al., 2003). More powerful statistical methods, including linkage disequilibrium (LD), identical-by-descent (IBD) and transmission disequilibrium test (TDT) have been proved to enable fine mapping of QTL regions in livestock (Riquet et al., 1999; Farnir et al., 2002).

The positional candidate approach is subsequently implemented to scrutinize for candidate genes according to their physiological function in the refined QTL region. The ultimate goal is to identify quantitative trait nucleotides (QTNs) in the 
candidate genes and validate the biological effects of QTNs using functional genomics tool (Andersson et al., 2004). The whole flowchart is shown in Figure 1. To date, the successful identification of the causative mutations that underlie complex traits in domestic animals is summarized in Table 1.

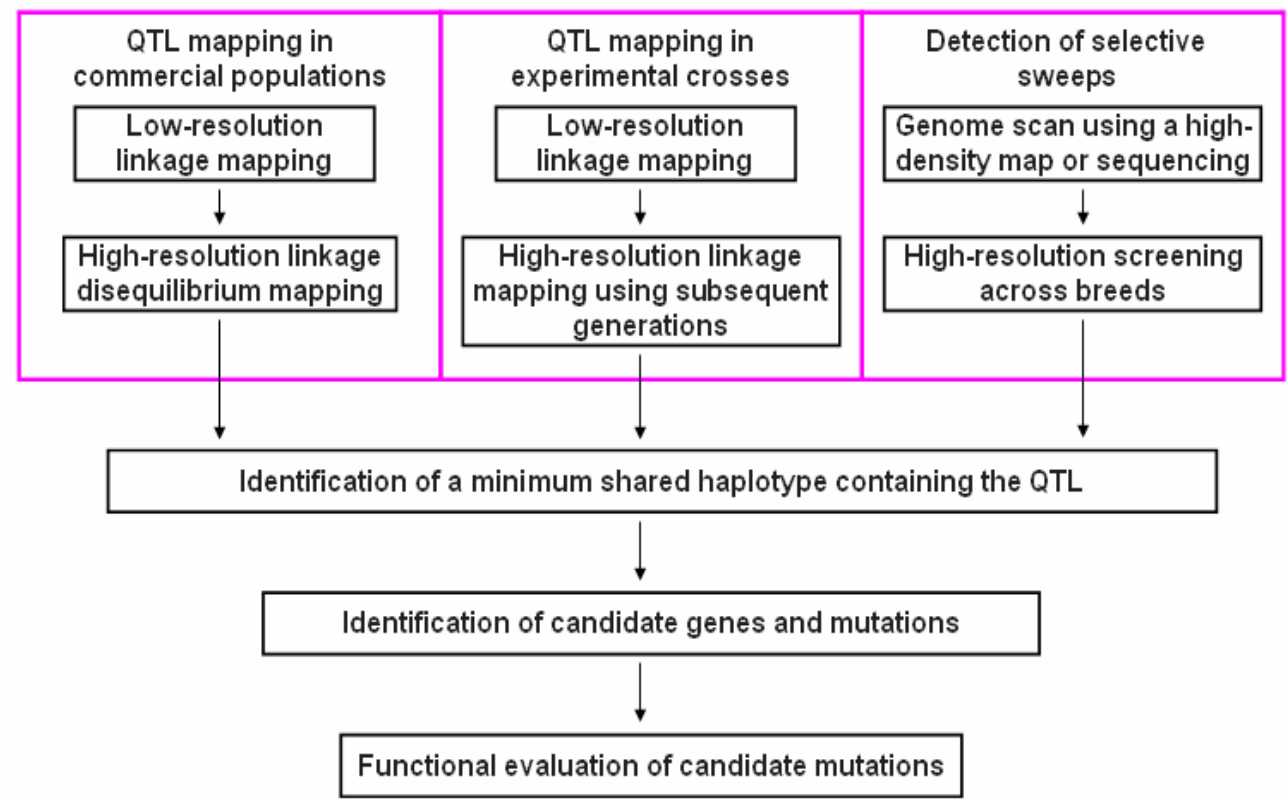

Figure 1. Approaches to mapping and positional cloning of QTLs in domestic animals.

(Cited from Andersson et al., 2004)

Table 1. QTNs for complex traits have been identified in livestock.

\begin{tabular}{ccccc}
\hline Species & Trait & Gene & QTN & Reference \\
\hline pig & muscle development & IGF2 & intron3-G3072A & Van Laere et al., 2003 \\
cattle & $\begin{array}{c}\text { milk yield and } \\
\text { composition }\end{array}$ & DGAT1 & K232A & Grisart et al., 2002 \\
& $\begin{array}{c}\text { milk yield and } \\
\text { composition }\end{array}$ & ABCG2 & Y581S & Cohen-Zinder et al., 2005 \\
& & & \\
sheep & muscular hypertrophy & GDF8 & 3'UTR-G6723A & Clop et al., 2006 \\
\hline
\end{tabular}




\section{Pig teat number}

\subsection{Inheritance of teat number}

With the improvement of pig reproductive performance, the teat number, especially the number of functional nipples becomes a more important trait regarding the mothering ability of sows; because a sow seldom weans more piglets than the number of the functional nipples it has (Hirooka et al., 2001). The pig industry has traditionally applied selection pressure to teat number (Pumfrey et al., 1980). The heritability of teat number varies in a wide range from 0.07 to 0.79 , but most of estimates are in a low to medium interval from 0.20 to 0.50 (Borchers et al., 2002).

The relationship between teat number and maternal performance is still controversial. Jungst et al. (1983) indicated that litter weights at 21 and 42 day were not affected by the number of teat. Pumfrey et al. (1980) showed that correlations between teat number and litter size, weight at birth, weight at weaning and ovulation rate were negative. But a recent investigation of the effects of teat number on litter size in Duroc, Landrace and Yorkshire gilts showed that 14 or more teats compared to 11-13 teats increased litter size at birth and 21 day weaning (Kim et al., 2005).

In addition, teat number in pigs is a discontinuous and often canalized trait presenting bilateral symmetry with only minor difference between the two sides (Toro et al., 1986), which makes it a good candidate to evaluate fluctuating asymmetry (FA) and developmental instability (Fernández et al., 2004). So the factors that affect the number of teats in pigs are of interest for both biological and practical reasons (Drickamer et al., 1999). In a Yorkshire population, no relationship between body length and number of nipples was detected (Johnson et 
al., 2003). A major gene responsible for the number of false teats (FTN) is strongly suggested to be present in a Chinese European pig line using likelihood and Bayesian analyses (Sanchez et al., 2003). Considering the limited information about the inheritance of teat number in comparison to other productive traits in pigs, a better understanding of the genetic control of this trait is still a real challenge.

\subsection{QTLs for teat number}

As a subtrait of fecundity in pigs, teat number is easily recorded in many mapping populations. A number of QTLs have been identified through whole-genome scans (Table 2) in recent years. It is worth to note that QTLs on SSC8, 10 and 12 overlap very well in several different experiments, in which Meishan pigs were used as the founder animals. These observations favor the hypothesis that one or more major genes for teat number are located respectively in these regions. Like most of economically important traits, the question now remains as the fine mapping of these QTLs and afterwards, the identification of the QTGs and QTNs. We will still need to know whether there are other QTLs for this trait which we have yet not identified.

\section{Pig inguinal/scrotal hernia}

Hernia is one of the most common congenital and developmental undesirable defects in pigs, commonly referred to as rupture in the industry, representing protrusion of part of an organ or tissue through the structures normally containing it (OMIA-Online Mendelian Inheritance in Animals, http://www.angis.org.au/bin/Databases/BIRX/birx_doc?omia+1082). Hernias can be classified as diaphragmatic, inguinal/scrotal, and umbilical/abdominal, depending on the location. The latter two are the more common ones. 
Table 2. QTLs for teat number in pigs.

\begin{tabular}{|c|c|c|c|c|c|}
\hline Population & SSC: Position (cM) & P-value ${ }^{1}$ & $a^{2}$ & $d^{3}$ & References \\
\hline $\begin{array}{l}\text { White composite } \times \text { Meishan } \\
\text { (reciprocal back-cross) }\end{array}$ & 10: 80 & $\mathrm{p}<0.01$ & - & - & Rohrer, 2000 \\
\hline $\begin{array}{c}\text { Goettingen Miniature } \hat{\delta} \times \\
\text { Meishan } q\end{array}$ & $\begin{array}{l}\text { 1: SJ029-SW485 } \\
\text { 7: SW859-SW147 }\end{array}$ & $\begin{array}{l}\mathrm{p}<0.01 \\
\mathrm{p}<0.001\end{array}$ & $\begin{array}{c}0.7^{* *} \\
0.47^{* *}\end{array}$ & $0.79^{* *}$ & Wada et al., 2000 \\
\hline $\begin{array}{c}\text { High-indexing line } \times \\
\text { control line (Both lines } \\
\text { derived from } \\
\text { Large White } \times \text { Landrace) }\end{array}$ & $\begin{array}{c}\text { 8: } 19 \\
11: 46 \\
15: 109\end{array}$ & $\begin{array}{l}\mathrm{p}<0.05 \\
\mathrm{p}<0.05 \\
\mathrm{p}<0.05\end{array}$ & $\begin{array}{c}-0.29^{*} \\
- \\
-\end{array}$ & $\begin{array}{c}- \\
0.67^{*} \\
-\end{array}$ & $\begin{array}{l}\text { Cassady et al., } 2001 \\
\text { Holl et al., } 2004\end{array}$ \\
\hline $\begin{array}{c}\text { Meishan } \widehat{\partial} \times \text { Dutch } \\
\text { Landrace/Large White } q\end{array}$ & $\begin{array}{c}2: 2 \\
10: 107 \\
12: 80\end{array}$ & $\begin{array}{l}\mathrm{p}<0.001 \\
\mathrm{p}<0.001 \\
\mathrm{p}<0.001\end{array}$ & $\begin{array}{r}-0.15 \\
0.35 \\
0.20\end{array}$ & $\begin{array}{l}- \\
-\end{array}$ & Hirooka et al., 2001 \\
\hline $\begin{array}{l}\text { Meishan x White } \\
\text { (reciprocal crosses) }\end{array}$ & $8: 49$ & $\mathrm{p}<0.05^{3}$ & - & $0.58^{* *}$ & King et al., 2003 \\
\hline Meishan $\hat{\sigma} \times$ Pietrain $q$ & $\begin{array}{l}\text { 1: } 169 ; 2: 73 \\
10: 142 ; X: 11\end{array}$ & $\mathrm{p}<0.05$ & - & - & Geldermann et al., 2003 \\
\hline Wild $\hat{\delta} \times$ Pietrain $q$ & $1: 171 ; 5: 28$ & $\mathrm{p}<0.05$ & - & - & Geldermann et al., 2003 \\
\hline Wild $\hat{\sigma} \times$ Meishan $q$ & $\begin{array}{c}1: 68 ; 8: 63 \\
10: 93 ; 12: 41\end{array}$ & $\mathrm{p}<0.05$ & - & - & Geldermann et al., 2003 \\
\hline Iberian $\hat{0} \times$ Meishan $q$ & $5: 29$ & $\mathrm{p}<0.05$ & 0.62 & - & Rodriguez et al., 2005 \\
\hline & $\begin{array}{l}10: 72 \\
12: 67\end{array}$ & $\begin{array}{c}\mathrm{p}<0.001 \\
\mathrm{p}<0.05\end{array}$ & $\begin{array}{l}0.71 \\
0.45\end{array}$ & $\begin{array}{l}- \\
-\end{array}$ & \\
\hline Meishan $\uparrow \times$ Duroc $\hat{\sigma}$ & $\begin{array}{c}\text { 3: } 117 ; 7: 97.1 ; \\
8: 62.9 \\
\text { 8: } 29.7 ; 12: 41.4\end{array}$ & $\begin{array}{l}\mathrm{p}<0.01 \\
\mathrm{p}<0.05\end{array}$ & - & - & Sato et al., 2006 \\
\hline
\end{tabular}

The economic loss caused by this defect in the pig industry is considerable vast each year in the world. Afflicted individuals cannot feed effectively and their growth is affected. This leads to higher feed costs, slower throughput, and lack of product uniformity, cheaper price for meat-selling and the consequent loss in income. Quite often such afflicted individuals also require extra health considerations - sick pens, drugs, labor, etc. - and hence lead to higher rearing costs. In a nucleus breeding population, such individuals cannot be considered for 
use as breeding stock and effectively end up as culls. Moreover, affected animal's welfare can't be guaranteed. There is also the risk that herniated pigs could die as a result of strangulation of the intestine in the umbilical or scrotal ring. Some groups in the world have devoted to decipher the genetic structure of this disorder. Identification of causative genes or causal mutations controlling pig herniation will allow for the reduction of occurring of hernia through marker-assisted selection (MAS).

At the same time, pig hernia is also a good model for research on human hernia (Chang et al., 1994). The progress will boost the investigating of molecular mechanism of human hernia formation.

\subsection{Epidemiology and inheritance of pig inguinal/scrotal hernia}

Incidence: The frequencies of pig inguinal/scrotal hernia differ among different environments and breeds. Due to its nature, pig inguinal/scrotal hernia is a sex-limited congenital malformation. It occurs with prevalence between $0.5-1.5 \%$ in different breeds. Researchers observed a significant difference among the progeny of Duroc, Landrace, and Yorkshire in developing scrotal hernia with incidences of $0.6 \%, 1 \%$ and $1.5 \%$, respectively (Vogt et al., 1990). It was also proposed that the incidence of inguinal/scrotal was relatively lower than $1 \%$ in Norwegian pigs (Lingaas et al., 1991). Thaller also showed a prevalence of $0.57 \%$ of scrotal hernia in Landrace and Pietrain populations (Thaller et al., 1996). Another study reported that the incidence rates of scrotal hernia were $1.36 \%$ and $1.31 \%$ in the Dutch herd-book Landrace and Large White Breeds, respectively. And the corresponding incidence rates for Hypor's European Landrace (D-line) and Large White (C-line) lines were $0.54 \%$ and $0.22 \%$, respectively (Charagu, 2006). So, an unusually high incidence, high than $2 \%$ herniated pigs of all piglets born, in a certain period of time should be concerned and further investigated, and all herniated animals and their littermates should be culled from nucleus breeding 
stock (Patrick et al., 2006).

Heritability: Heritability of the susceptibility to scrotal hernia development reported in the literature is relatively moderate. Vogt et al. (1990) showed the heritability for this abnormality was $0.29 \pm 0.17,0.34 \pm 0.23$, and $0.34 \pm 0.19$ in Duroc, Landrace, and Yorkshire-sired pig groups, respectively based on 5,711 Duroc-sired, 2,227 Landrace-sired and 2,494 Yorkshire-sired male pigs born over a 9-year period. Percentage of affected pigs among male full siblings of affected males was about 3.0 times greater than the overall percentage affected in their respective breed groups. But an even earlier estimation showed a higher heritability of scrotal hernia in two herds up to 0.65 and 0.86 , respectively (Mikami et al., 1979). Recognition of genetic modeling of inguinal/scrotal hernias went through a series of changes from a single gene with incomplete dominance (Berge et al., 1941) to double recessive genes (Hutson et al., 1978), and from polygenic inheritance (Magee, 1951; Knap, 1986; Wrathall, 1988) to major gene effects with a polygenic background variation with relatively low heritability between 0.029 and 0.187 (Thaller et al., 1996).

\subsection{Etiology of inguinal/scrotal hernia}

As a complex genetic defect, it has been a long way to understand the nature of inguinal/scrotal herniation. Even then there are debates regarding the etiopathogenesis of this disease, three aspects have been highlighted to explore the probable causes of hernia inguinalis/scrotalis in past decades: patent processus vaginalis, altered collagen metabolism and testicular descent.

\subsubsection{Obliteration of processus vaginalis}

In human, indirect hernias are developed from incomplete obliteration of the processus vaginalis (PV), the embryological protrusion of peritoneum that precedes the descent of the testis. The testes originate along the urogenital tract in 
the retroperitoneum and migrate during the second trimester of pregnancy to the deep inguinal ring, where they arrive after 6 months of gestation. During the last trimester, they proceed through the abdominal wall via the inguinal canal and descend into the scrotum. Normally the processus vaginalis postnatally obliterates (Figure 2). Failure of this process results in a patent processus vaginalis (PPV) and possibly in an indirect inguinal hernia. Failure of closure of the processus vaginalis accounts for nearly all the inguinoscrotal abnormalities seen in infancy and childhood (Bonnard et al., 2003). Van Wessem et al. (2003) showed that the etiology of indirect inguinal hernia is congenital.

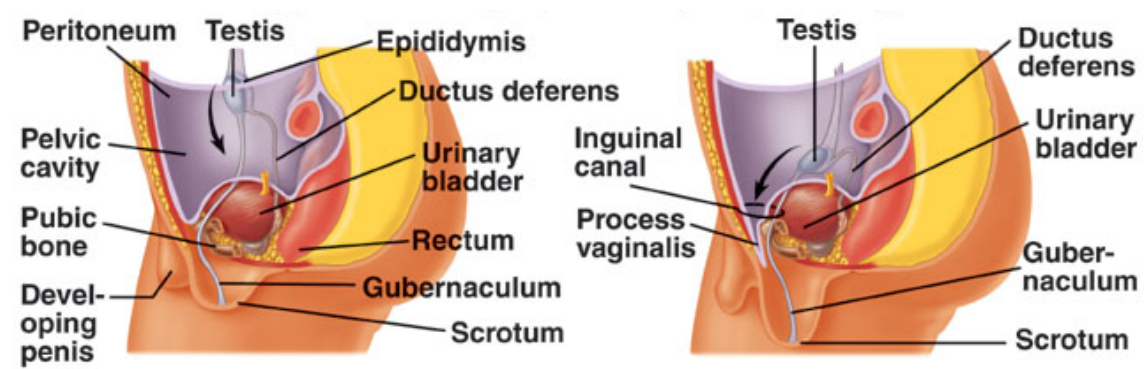

(a) Approximately 2 months

(b) Approximately 3 months

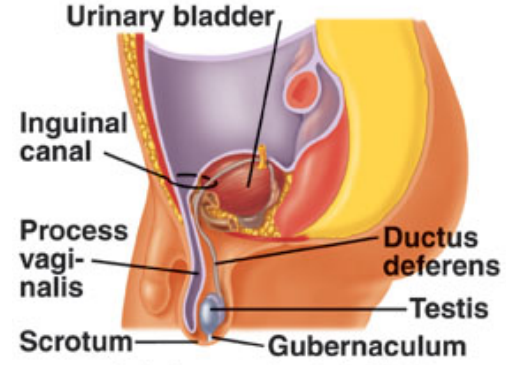

(c) Approximately birth

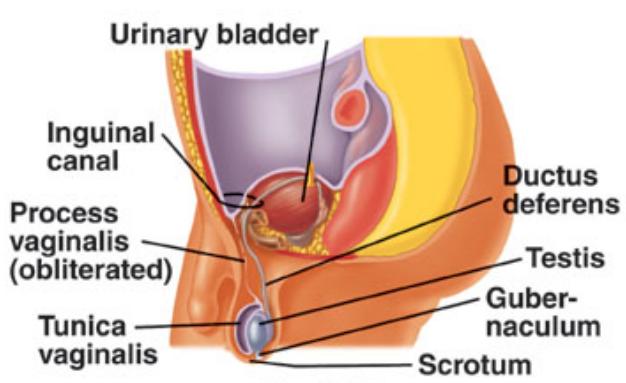

(d) Adult

Figure 2. Scheme of the development and obliteration of process vaginalis in the descent of testes in human. (Robert et al., 2004)

The testis is descended through the processus vaginalis via the propulsive force generated by the muscles derived from the gubernaculum (Tanyel et al., 2000). Since the obliterated processus vaginalis is devoid of smooth muscle, and since sacs associated with inguinal hernia present more smooth muscle, the obliteration of the processus vaginalis after descent appears to mandate the disappearance of 
smooth muscle (Tanyel et al., 1999), i.e. disappearance of smooth muscle is necessary for the closure of the processus vaginalis. So after propelling the testis, the smooth muscle should undergo programmed cell death (PCD) for obliteration of the processus vaginalis, its failed apoptosis may persist processus vaginalis (Tanyel, 2000). Dedifferentiation into myofibroblast appears to be an important step that increases susceptibility of smooth muscle for programmed cell death (Tanyel et al., 2002). There is no evidence of depletion of stores in cremaster muscles or overload of calcium in sacs associated with inguinal hernia (Tanyel et al., 2003), while inhibition of $\mathrm{Ca}^{2+}$ load inhibits PCD.

The probable pathway of obliteration of processus vaginalis was proposed by Tanyel et al. (2004) and Tanyel (2004a) (Figure 3). The initial step appears to be the activation of phospholipase $\mathrm{C}$ via G-protein-linked signal transduction. Depletion of $\mathrm{Ca}^{2+}$ stores with an increase in cytosolic $\mathrm{Ca}^{2+}$ is succeeded by mitochondrial $\mathrm{Ca}^{2+}$ overload. Increases in Bax and Fas and regulated targeting of Bax to mitochondria initiate the cascade of PCD, which involves a family of proteases called caspases which are activated through two main pathways: extrinsic pathway and intrinsic pathway (Reed, 2000). The disappearance of the smooth muscle is followed by the disappearance of the mesothelium, thus the obliteration of the PV. In this pathway, activation of phospholipase C in smooth muscle is accomplished by parasympathetic influences. The parasympathetic system depends less on androgens. The increase in parasympathetic tonus is accomplished through a decrease in sympathetic tonus via up-regulation of afferent neurotransmitters under control of androgen receptors.

The dominance of parasympathetic tonus through a decrease in sympathetic tonus via an androgen receptor-dependent increase in afferent neurotransmitters at a critical time appears to be mandatory for the obliteration of PV through the PCD 
of smooth muscle. Absence or inadequacy, inappropriate duration, and inappropriate timing of parasympathetic dominance affect both calcium signaling and the inducers of apoptosis and results in an inguinal hernia, hydrocele, or abnormal testicular localization.

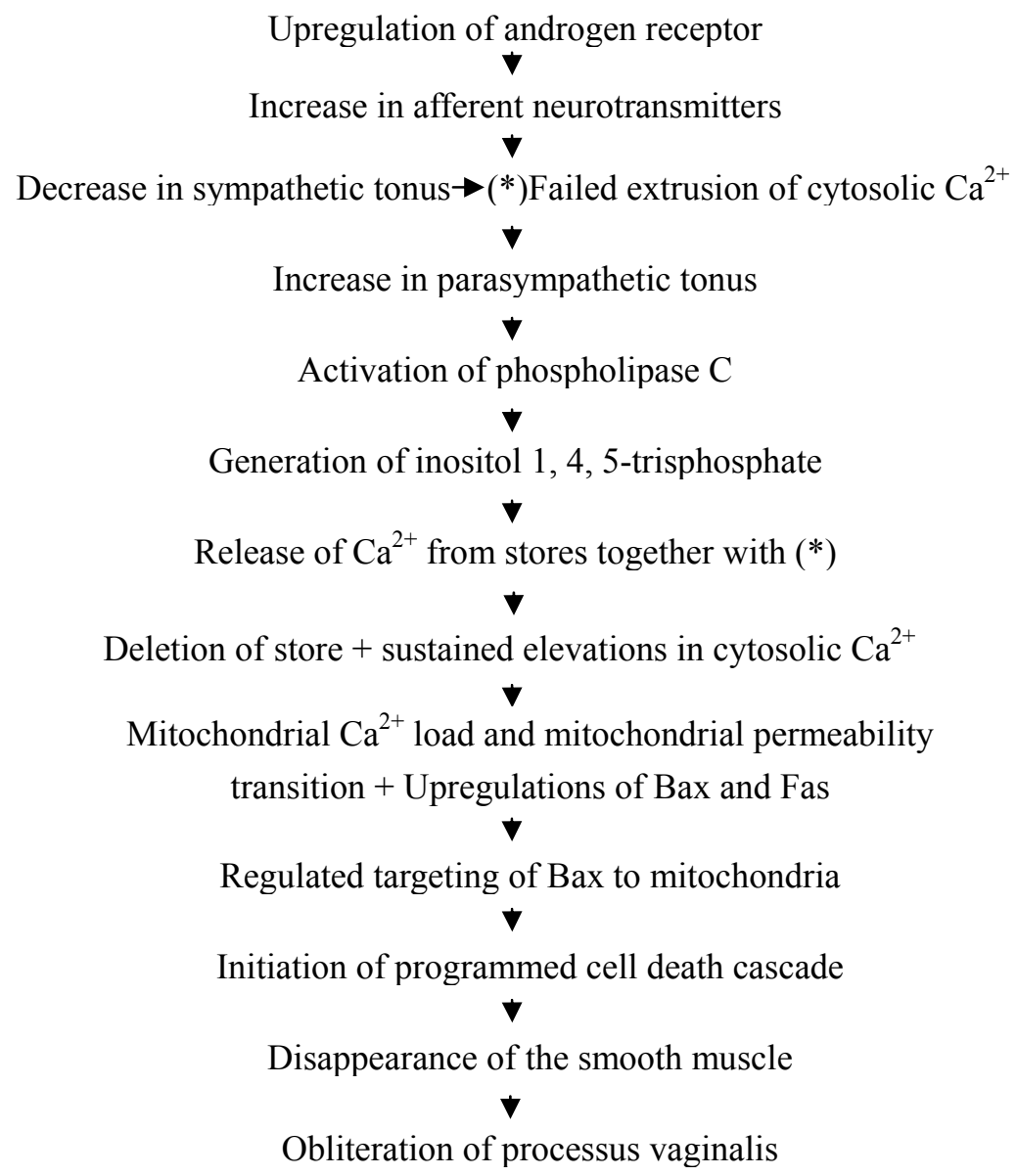

Figure 3. The possible pathway of obliteration of processus vaginalis. (Tanyel et al., 2004)

\subsubsection{Testicular descent}

In the early fetus, the undetermined ambisexual gonad lies in peri-renal position. Through a cascade pathway regulated by a series of genes, including the testis-determining gene (SRY), the steroidogenic factor 1 (SF1) and the 
SRY-related HMG box gene (SOX9), the testis was determined. Then the primitive sex cords in the medullary region of the primitive gonad differentiate into Sertoli cells. The Sertoli cells secrete the glycoprotein hormone Müllerian inhibiting substance (MIS) which causes regression of the Müllerian duct in the male fetus. Leydig cells are differentiated from the mesenchymal cells of the genital ridge and secrete testosterone which influences the differentiation of the Wolffian duct into the epididymis, vas deferens and seminal vesicle (Clarnette et al., 1997). These anatomical changes are presented in the testicular descent (Figure 4).

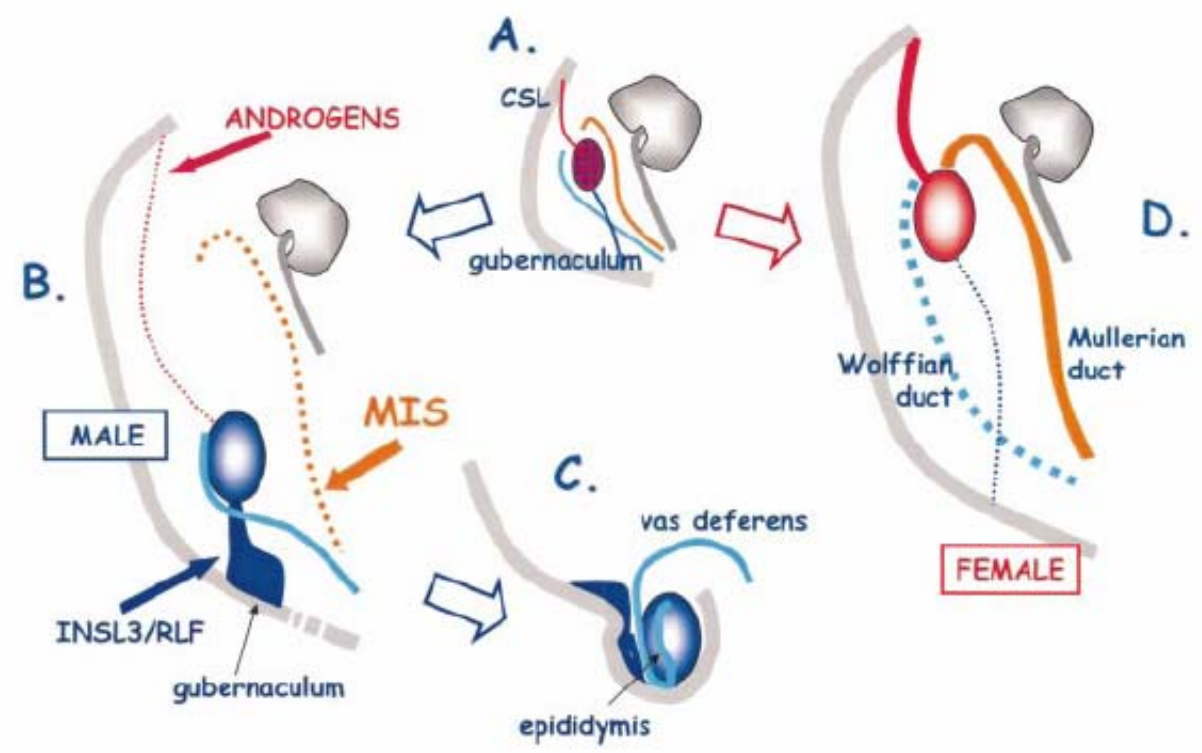

Figure 4. Schematic illustration of the events involved in the descent of the differentiating testis from a peri-renal to an inguinal position.

CSL: the cranial suspensory ligament; INSL3/RLF: insulin-like factor-3/relaxin-like factor; dot line: disappearance of anatomical structure. (Ivell et al., 2003)

The processus vaginalis is closely associated with the mechanism of testicular descent. Testicular descent is a complex developmental process. During the last twenty years, the understanding of this process has been enriched. The process of testicular descent is now proposed to be occurred in two sequential steps with different anatomical mechanisms and different hormonal controls. Two 
comprehensive reviews have led to a profound insight into this two-stage hypothesis (Hutson et al., 2005) and its molecular basis (Ivell et al., 2003). The first phase was suggested to be controlled by Müllerian inhibiting substance (MIS) (also known as anti-Müllerian hormone, $\mathrm{AMH}$ ), while the second phase was proposed to be dependent on androgens (Table 3).

Table 3. Anatomical phases of testicular descent and their hormonal control.

(Hutson et al., 2004)

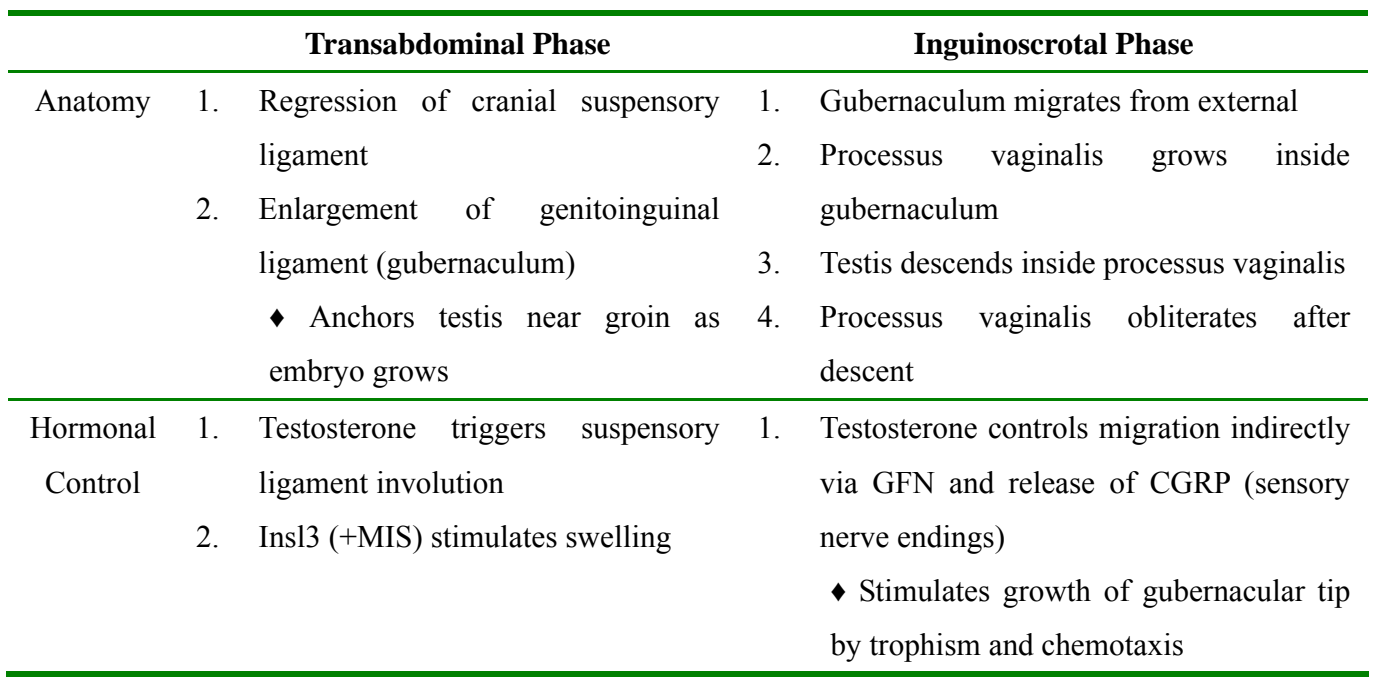

Transabdominal phase: The gubernaculum (genitoinguinal ligament) plays a pivotal role in the first phase of testicular descent. It enlarges by mitosis and deposition of hyaluronic acid (Heyns et al., 1990) and holds the testis near the inguinal canal (Van der Schoot et al., 1992), in which muscles form around the mesenchymal end of the gubernaculum. It is assumed that myogenesis occurs within gubernaculum to provide physical force for the descent of the testis (Tanyel, 2004b). Until now, at least three kinds of hormones are suggested to control the first step. Androgen causes cranial suspensory ligament (CSL) regression and insulin-like peptide 3 (INSL3) (also known as relaxin-like factor, RLF) causes the gubernacular swelling reaction (Nef et al., 1999; Zimmermann et al., 1999; Kubota et al., 2001; Smith et al., 2001; Tomiyama et al., 2003), which is 
augmented by Müllerian inhibiting substance/anti-Müllerian hormone (MIS/AMH) (Hutson et al., 1987) and androgen (Kubota et al., 2002).

Inguinoscrotal phase: the gubernaculum is proposed to migrate from the external inguinal ring to the scrotum. Simultaneously the gubernaculum becomes hollowed out by a diverticulum of the peritoneum, tunica vaginalis, to allow the intra-abdominal fetal testis to reach the scrotum. Following complete descent, the peritoneum proximal to the testis obliterates to prevent development of an inguinal hernia. This inguinoscrotal phase is controlled by release of calcitonin gene-related peptide (CGRP) from genitofemoral nerve (GFN) under stimulation of androgen (Hutson et al., 1997). CGRP has been shown to cause obliteration of the patent peritoneal sac in inguinal hernia in babies; however, the signaling pathway is still unknown.

Based on advanced of mechanism of testicular descent, the gubernaculum is the key anatomical structure in control of testicular descent; it plays an essential role in the complex mechanism of testicular descent and inguinal hernia closure.

\subsubsection{Collagen hypothesis}

It is well known that an indirect inguinal hernia usually occurs through an unobliterated processus vaginalis, whereas a direct inguinal hernia appears through a weak area and repeated elevation of intra-abdominal pressure. It is likely that more factors than a patent processus vaginalis along are needed to develop an indirect inguinal hernia. High abdominal pressure and weakening of the abdominal muscles can activate herniation. Interestingly, older human patients with inguinal hernia are usually reported to have a defect in the transversalis fascia (Peacock et al., 1974). Moreover, there are often high recurrence rates of inguinal hernias after physical strength has been restored by surgical mesh-free procedures (Lichtenstein et al., 1993). Obviously, the defect in the fascia 
transversalis plays a pivotal role in the development of inguinal hernias.

The transversalis fascia is a fascial envelop of the abdomen and competency of the deep inguinal ring depends on the integrity of this fascia. And the fascia transversalis is a connective tissue composed of a framework of elastic and collagen fibers, which supports the abdominal tension forces. The distension and biological elasticity of the fascia transversalis significantly increased in hernia patients (Pans et al., 1997). Significantly lower amounts of collagen and higher amounts of elastic fibers in transversalis fascia are observed in patients with direct inguinal hernia than those with indirect inguinal hernia (Pans et al., 2001; Rodrigues et al., 2002). A point mutation $(28197 \mathrm{~A}>\mathrm{G})$ in the elastin $(E L N)$ gene leads to an S422G amino acid substitution in the elastin hydrophobic domain, it shows a statistically significant association with inguinal hernia (Rodrigues et al., 2006), possibly due to abnormal elastic fiber and impaired fascia transversalis function. A marked reduction of the collagen $\mathrm{I} / \mathrm{W}$ ratio respective in the fascia transversalis, hernial sac and skin of individuals with inguinal hernias compared with controls was demonstrated by immunohistochemistry and Western Blot analysis (Klinge et al., 1999a, 1999b and 1999c). In a sequent experiment, the ratio of type I to type $\amalg$ procollagen mRNA was also significantly decreased in cultured fibroblasts from the skin of patients with primary inguinal hernia as compared to controls (Rosch et al., 2002). The decreased ration was mainly due to the increase of type Ш collagen.

The main collagen types found in connective tissues are fibrillar types I, П, Ш and XI, with collagen type I being the most abundant protein in humans. The amount and the ration of synthesized and deposited collagens type I and type Ш determine the quality of connective tissue. Particularly mature type I collagen, predominantly found in dense bundles in connective tissues like tendons or ligaments, is responsible for the tensile strength of tissue. In contrast, type III collagen, consisting 
of thinner fibres, represents immature collagen found in early wound healing and in flexible tissues (Wiedemann et al., 1975). Moreover, collagen types I and III play an important role in regulating fibrillogenesis, formation of fibril diameters and bundle architecture. With reduced ratio of type I to type III collagen, the geometrical arrangement and diameter of collagen fibrils changes and cross-linking decreases, that leads to reduced mechanical stability (Fleischmajer et al., 1990).

So the altered metabolism of collagen may play a pivotal role in the pathogenesis of inguinal hernia formation. It had been reported that connective tissue disorders, such as osteogenesis imperfecta, Marfan's, Ehlers-Danlos, hip dislocation of childhood may predispose individuals to the development of inguinal hernia probably through the interference of collagen metabolism. Autosomal dominant polycystic kidney, known to have abnormal extracellular matrix production is associated with a 43\% incidence of hernias (Morris-Stiff et al., 1997). In a study in Sweden by Uden and Lindhagen, children with congenital hip dislocation revealed that boys had a 3 times increase in incidence of herniation, while girls showed a 5 times increase (Uden et al., 1988). In a series of hypermobile children, $33 \%$ had hernias, compared to 5\% in a normal population (Friedman et al., 1993).

Bendavid (2004) proposed one single unified theory of hernia formation through reviewing progresses of herniation in multiple disciplines including anatomy, genetics, biochemistry, pathology and molecular biology. The theory is that the pathological changes in collagen set the stage for the development of a hernia. This new concept of hernia biology was also put forward by Jansen et al. (2004) (Figure 5). 


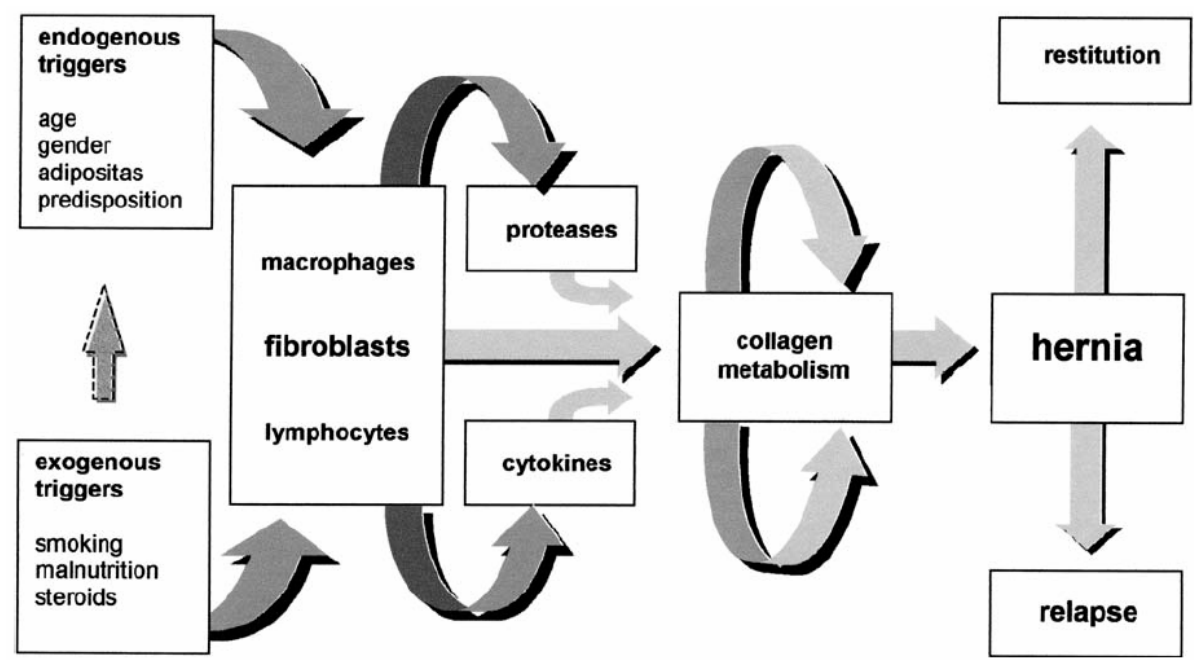

Figure 5. Pathogenesis of hernia formation. (Jansen et al., 2004)

From above, the genes related to collagen metabolism, including collagen genes and genes of matrix metalloproteinases (MMPs) which degrade and remodel collagens can be considered as candidates for inguinal herniation.

\subsection{Molecular progress for hernia inguinalis/scrotalis in pigs}

In recent years, several groups have devoted to deciphering the genetic architecture of inguinal/scrotal hernia. Grindflek et al. (2006) detected 9 significant QTLs $(\mathrm{p}<0.01)$ on 8 porcine chromosomes in a population of 194 individuals including 103 affected sib pairs (ASP) through a genome-wide linkage analysis. And the effects of 6 genomic regions on 6 chromosomes were genome level significant $(\mathrm{p}<0.01)$ using transmission/disequilibrium test (TDT). Two significant regions $(\mathrm{p}<0.01)$ at SW963 on SSC5 and at SW1891 on SSC17 were significant convincing by both ASP test and TDT. Five regions located on SSC1, SSC2, SSC6, SSC15 and SSCX were found to be highly significant $(\mathrm{p}<0.005)$ by either the ASP test or the TDT. Moreover, six significant haplotypes $(p<0.01)$ were constructed, of which one haplotype SW963-SWR1526 was transmitted to hernia pigs with four times higher frequency than to healthy pigs $(\mathrm{p}<0.00005)$. 
Du et al. (2004) performed a whole-genome scan using 7 independent scrotal hernia-affected paternal families from 3 commercial pig lines, and identified 3 chromosomes with suggestive statistical evidence for segregation of scrotal hernia genes by an identity-by-descent based nonparametric linkage analysis. QTLs on SSC2 and SSC12 were confirmed by genotyping 27 additional paternal scrotal families for 33 microsatellites markers on the three chromosomes. The QTL regions were refined by identifying 137 polymorphic SNPs (107 on SSC2 and 30 on SSC12) and genotyping approximately 2000 pigs from 147 Pietrain paternal families (with at least 1 affected progeny or at least 80 progeny all absent of scrotal hernia)(Du, personal communication).

Pig Improve Company (PIC) had conducted a comprehensive gene discovery program to identify markers for scrotal hernia (Plastow et al., 2003). Using candidate gene approach (over 40 markers from more than a dozen genes were ultimately investigated) as well as a genome scan approach (using $\mathrm{AFLP}^{\mathrm{TM}}$ and microsatellite markers), two markers in two different genomic regions were detected to have a strong association with the BLUP EBV system for scrotal hernia in one of the pure lines.

In our group, a genome-wide scan based on affected porcine half-sib families was performed. The pedigree consists of 84 families with a total of 512 animals including 81 boars, 156 sows and 275 affected piglets among them, was genotyped for 139 DNA-markers distributed across the 18 autosomes. Significant QTLs on chromosomes 3, 6, 7, 12 and 15 were mapped by non-parametric linkage analysis (Knorr et al., 2006). Fine mapping is ongoing. A number of candidate genes for hernia inguianlis/scrotalis, including INSL3, GUSB and CALCA were also evaluated (Knorr et al., 2002a, 2002b and 2004; Beck et al., 2006). 


\section{The SOX9 gene}

The SOX (SRY-box) genes are developmental regulators which are characterized by the presence of a 79 amino acid high mobility group (HMG) DNA-binding domain with $>50 \%$ homology to the sex-determining gene SRY. The SOX gene family can be further subdivided into twelve subgroups defined by additional homologies outside of the DNA-binding domain (Bowles et al., 2000). SOX9 belongs to subgroup E and is well characterized. SOX9 gene is involved in a wide range of developmental processes, including chondrogenesis, sex determination (Foster et al., 1994; Wagner et al., 1994) and the development of the neural crest (Spokony et al., 2002) and the spinal cord glial cells (Stolt et al., 2003).

\subsection{Biological/physiological function of SOX9}

\subsubsection{Function in the development of male gonad}

As a target gene of SRY, SOX9 plays key roles in regulating the male developmental pathway (Figure 6). There has been a substantial amount of evidence supporting an important role for SOX9 in the sex determination, a process defined as the commitment of the indifferent gonad to a testis or an ovary. Huang et al. (1999) showed that a duplication of the genomic region containing the SOX9 gene caused female-to-male sex reversal. Ectopic expression of SOX9 in undifferentiated gonads induces testis development resulted in all XX transgenic mice (Vidal et al., 2001). Moreover, transgenic insertion of a tyrosinase minigene $\sim 1 \mathrm{Mb}$ upstream of the SOX9 gene in Odsex mice was associated with XX male development lacking $S R Y$, presumably due to the inactivation of a repressor element that normally inhibits SOX9 expression in ovaries (Bishop et al., 2000). In pigs, SOX9 was down-regulated in XX gonads and up-regulated in XY from $28 \mathrm{dpc}$ (days post coitum), the up-regulation of the SOX9 gene was concomitant with appearance of differentiated Sertoli cells 
(Parma et al., 1999). Pig SOX9 can also retroactivate the pig SRY promoter via a SOX9 binding site at position -205 from the ATG translational start site (Daneau et al., 2002). These evidences show that the constitutive expression of SOX9 in the dimorphic gonad appears to be required and sufficient to promote testis determination (Chaboissier et al., 2004; Qin et al., 2005).

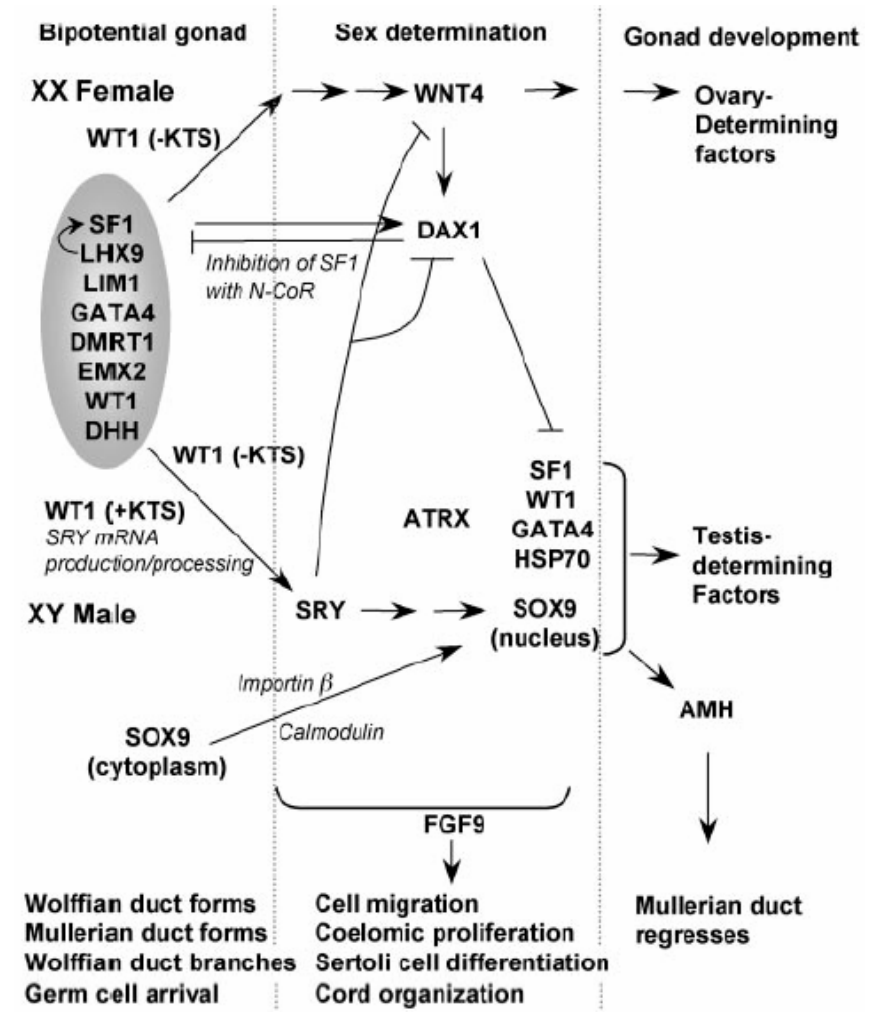

Figure 6. Model for initiation of sex determination (Harley et al., 2005) .

SOX also acts an important role in sex differentiation. SOX9 can bind to the promoter region of the human anti- Müllerian hormone gene $(A M H)$ which is responsible for regression of Müllerian ducts during male sex differentiation, and activates transcription of the $A M H$ gene together with steroidogenic factor 1 (SF-1) (de Santa Barbara et al., 1998). AMH is an essential component of the male sexual differentiation pathway, secreted by Sertoli cells, causing the regression of the Müllerian ducts. SOX9 is essential for $A M H$ transcription. Mice with targeted 
mutations in the SOX9 site within the $A M H$ promoter result in a complete absence of $A M H$ transcript and complete retention of Mullerian duct-derived organs (Arango et al., 1999).

In addition, it was speculated that SOX9 has function on testicular descent via a cascade pathway despite no direct evidences were reported. It has been shown that SOX9 can up-regulate the expression of SF-1 (Shen et al., 2002). SF-1 affects transcription of INSL3 by its binding within INSL3 promoter (Zimmermann et al., 1998; Koskimies et al., 2002; Truong et al., 2003) and INSL3 receptor GREAT/LGR8 (G protein-coupled receptor affecting testicular descent/Relaxin receptor 8) (Adham et al., 2004). At last, INSL3 and its receptor GREAT/LGR8 act as the critical regulator of the gubernacular differentiation by a speculated involvement of the control of the collagen metabolism and reorganization of extracellular matrix (Adham et al., 2004). Furthermore, AMH plays a role in augmenting gubernacular growth (Kubota et al., 2002). Therefore, SOX9 is associated with male sex-determination pathway, testicular descent and collagen metabolism.

\subsubsection{Function in collagen metabolism}

It has been well established that SOX9 has essential roles in successive steps of the chondrocyte differentiation (Akiyama et al., 2002 and 2004) and cartilage formation which is composed of collagen fibrils assembled from mature type II, type IX and type XI collagen molecules (Bell et al., 1997; Bi et al., 1999; Lefebvre et al., 1997). SOX9 loss-of-function mutations cause the skeletal malformation syndrome campomelic dysplasia, a lethal skeletal malformation syndrome and XY sex reversal (Foster et al., 1994; Wagner et al., 1994). Haploinsufficiency of SOX9 results in defective cartilage primordia and premature skeletal mineralization (Bi et al., 2001). Expressions of the $\alpha 1$ chain of 
type II collagen gene (Col2a1), collagen $\alpha 2$ (XI) gene (Col11a2) and type XXVII collagen gene (Col27a1) are cis-regulated by SOX9 through its interaction with the SOX9-binding site on the enhancer region (Bell et al., 1997; Bridgewater et al., 1998; Jenkins et al., 2005).

\subsubsection{Function in apoptosis}

As a transcription factor with a crucial role in normal development, SOX9 induces genes involved in cellular differentiation, resulting in the formation of mature cells susceptible to senescence and apoptosis. Until now, accumulated evidences suggest that SOX9 controls cell apoptosis. Akiyama et al. (2002) performed an elaborate experiment and proved SOX9 controls, either directly or indirectly, anti-apoptotic molecules such as Noggin and Chordin that inhibit signals (e.g. BMPs) responsible for formation of interdigital spaces. Inactivation of SOX9 in SOX9 $9^{\text {flox/flox }}$ mice, Prx1-Cre limb mesenchyme results in markedly increase apoptosis, an increased expression of Bax, and an increase in cleaved caspase 3 production.

Drivdahl et al. (2004) showed that SOX9 acts as a tumor suppressor in M12 prostate cancer cells by inhibiting proliferation through causing cell cycle arrest in G0/G1and increasing sensitivity to apoptosis. In the colon carcinoma cell line HT29C1.16E, SOX9 down-regulated the carcinoembryonic antigen (CEA), a tumor marker that is up-regulated in many types of human cancers, and up-regulated CEACAM1 which is a human tumor suppressor (Jay et al., 2005; Zalzali et al., 2006). The function of SOX9 on apoptosis may depend on the context of cells. Further evidences are required.

\subsection{Molecular structure and features of the SOX9 gene}

Human SOX9 had been localized to 17q24.3-q25.1 (Tommerup et al., 1993). While the porcine SOX9 gene was assigned to SSC12p13-11 by porcine somatic 
cell hybrid panel analysis (Lahbib-Mansais et al., 1997), this region is homologous to human SOX9 location. The human SOX9 gene contains three exons and encodes a protein of 509 amino acids (Wagner et al., 1994). An analysis of the structure and function of the mouse SOX9 promoter identified a proximal promoter region spanning from -193 to $-73 \mathrm{bp}$, which is in part responsible for the sex- and tissue-specific expression of the SOX9 gene (Kanai et al., 1999). This proximal promoter region is moderately conservative between mouse and human, and contains several conserved regulatory elements, including CCAAT box, GATA and CREB binding sites (Colter et al., 2005). Moreover, the spatiotemporal expression pattern of SOX9 is regulated by a complex set of widely spaced tissue-specific enhancers, located in the immediate vicinity of the transcription start site , up to $251 \mathrm{~kb} 5$ ' and up to $95 \mathrm{~kb}$ 3' to SOX9 (Bagheri-Fam et al., 2006). Morishita et al. (2001) also identified a 30-bp element in the first intron of human SOX9 gene acting as an enhancer.

Three functional domains are recognized for SOX9 so far, a high-mobility group (HMG) DNA-binding domain, a C-terminal transactivation domain and a DNA-dependent dimerization domain (Sudbeck et al., 1996; Sock et al., 2003). The sequence-specific DNA binding, DNA bending, and transactivation properties of SOX proteins suggest that these proteins act as transcription factors with characteristics of both classical transcription factors and architectural chromatin factors (Bell et al., 1997; Lefebvre et al., 1997). Moreover, SOX9 may have an additional function during pre-mRNA splicing (Ohe et al., 2002). In vitro studies demonstrate that the HMG domains of all SOX proteins tested to date bind with high affinity to a consensus DNA sequence (A/T A/T CAA A/T G) (Denny et al., 1992). Several investigators have suggested that SOX proteins bind to this core motif with different affinities, which is determined by sequences adjacent to the core motif (Collignon et al., 1996; Kamachi et al., 1999; Mertin et al., 1999). 
Mertin et al. (1999) showed the 5'AG and 3'GG flanking nucleotides enhance the affinity of SOX9 HMG domain. It has been known that mutations in the DNA-binding or transcriptional-activation domain of SOX9 can cause campomelic dysplasia (Foster et al., 1994; Wagner et al., 1994). The second domain essential for SOX9 function is a proline/glutamine/serine (PQS)-rich C-terminal transcription-activation domain. The potency of this domain is enhanced by a proline/glutamine/alanine (PQA)-rich motif which is unable to activate transcription alone. The $\mathrm{SOX} 9$ protein is known to activate transcription of the type II collagen gene and anti-Müllerian hormone gene. The third domain was just recently characterized as a dimerization domain in a conserved region immediately preceding the HMG domain (Sock et al., 2003).

\section{Aims of the thesis}

The objectives of this thesis were:

- $\quad$ To identify QTLs affecting pig teat number in a White Duroc $\times$ Erhualian resource population using genome-wide microsatellite scanning.

- To characterize the porcine SOX9 gene as a positional candidate gene for hernia inguinalis/scrotalis, evaluate the association of its genetic variation with pig inguinal/scrotal hernia, and characterize the probable molecular mechanism underlying the genetic effects. 


\section{References}

Adham IM and Agoulink AI. (2004) Insulin-like 3 signalling in testicular descent. International Journal of Andrology, 27, 257-265.

Akiyama H, Chaboissier MC, Martin JF, Schedl A and de Crombrugghe B. (2002) The transcription factor Sox9 has essential roles in successive steps of the chondrocyte differentiation pathway and is required for expression of Sox 5 and Sox6. Genes and Development, 16, 2813-2828.

Akiyama H, Lyons JP, Mori-Akiyama Y, Yang X, Zhang R, Zhang Z, Deng JM, Taketo MM, Nakamura T, Behringer RR, McCrea PD and de Crombrugghe B. (2004) Interactions between Sox9 and beta-catenin control chondrocyte differentiation. Genes and Development, 18, 1072-1087.

Andersson L and Georges M. (2004) Domestic-animal genomics: deciphering the genetics of complex traits. Nature Review Genetics, 3, 202-212.

Arango NA, Lovell-Badge R and Behringer RR. (1999) Targeted mutagenesis of the endogenous mouse Mis gene promoter: in vivo definition of genetic pathways of vertebrate sexual development. Cell, 99, 409-419.

Bagheri-Fam S, Barrionuevo F, Dohrmann U, Günther T, Schüle R, Kemler R, Mallo M, Kanzler B and Scherer G. (2006) Long-range upstream and downstream enhancers control distinct subsets of the complex spatiotemporal Sox9 expression pattern. Developmental Biology, 291, 382-397.

Beck J, Bornemann-Kolatzki K, Knorr C, Taeubert H and Brenig B. (2006) Molecular characterization and exclusion of porcine GUSB as a candidate gene for congenital hernia inguinalis/scrotalis. BMC Veterinary Research, 2, 14.

Bell DM, Leung KK, Wheatley SC, Ng LJ, Zhou S, Ling KW, Sham MH, Koopman P, Tam PP and Cheah KS. (1997) SOX9 directly regulates the type-II collagen gene. Nature Genetics, 16, 174-178.

Bendavid R. (2004) The unified theory of hernia formation. Hernia, 8, 171-176.

Berge S. (1941) The inheritance of paralysed hind legs, scrotal hernia and atresia ani in pigs. Journal of Heredity, 32, 271-274.

Bi W, Deng JM, Zhang Z, Behringer RR and de Crombrugghe B. (1999) Sox9 is required for cartilage formation. Nature Genetics, 22, 85-89. 
Bi W, Huang W, Whitworth DJ, Deng JM, Zhang Z, Behringer RR and de Crombrugghe B. (2001) Haploinsufficiency of Sox9 results in defective cartilage primordia and premature skeletal mineralization. Proceedings of the National Academy of Sciences USA, 98, 6698-6703.

Bishop CE, Whitworth DJ, Qin Y, Agoulnik AI, Agoulnik IU, Harrison WR, Behringer RR and Overbeek PA. (2000) A transgenic insertion upstream of sox9 is associated with dominant XX sex reversal in the mouse. Nature Genetics, 26, 490-494.

Bonnard A and Aigrain Y. (2003) Inguinal hernias in children. La Revue du Praticien, 53, 667-670.

Borchers N, Reinsch N and Kalm E. (2002) Teat number, hairiness and set of ears in a Pietrain cross: variation and effects on performance traits. Archiv für Tierzucht, 5, 465-480.

Bowles J, Schepers G and Koopman P. (2000) Phylogeny of the SOX family of developmental transcription factors based on sequence and structural indicators. Developmental Biology, 227, 239-255.

Bridgewater LC, Lefebvre V and de Crombrugghe B. (1998) Chondrocyte-specific enhancer elements in the Col11a2 gene resemble the Col2a1 tissue-specific enhancer. Journal of Biological Chemistry, 273, 14998-15006.

Carlborg O and Andersson L. (2002) Use of randomization testing to detect multiple epistatic QTLs. Genetical Research, 2, 175-184.

Cassady JP, Johnson RK, Pomp D, Rohrer GA, Van Vleck LD, Spiegel EK and Gilson KM. (2001) Identification of quantitative trait loci affecting reproduction in pigs. Journal of Animal Science, 3, 623-633.

Chaboissier MC, Kobayashi A, Vidal VIP, Lützkendorf S, van de Kant HJG, Wegner M, de Rooij DG, Behringer RR and Schedl A. (2004) Functional analysis of Sox8 and Sox9 during sex determination in the mouse. Development, 131, 1891-1901.

Chang KS and Chang JHT. (1994) Animal models of pediatric surgical diseases. Pediatric Surgery International, 9, 307-322.

Charagu PK. (2006) Congenital defects in pigs: 1. hernias and ridglings. http://www.hypor.com/dbdocs//43147ed874b22.pdf.

Chen KF, Knorr C, Bornemann-Kolatzki K, Ren J, Huang LS, Rohrer GA and Brenig B. (2005) Targeted oligonucleotide-mediated microsatellite identification (TOMMI) from large-insert library clones. BMC Genetics, 6, 54 . 
Clarnette TD, Sugita Y and Hutson JM. (1997) Genital anomalies in human and animal models reveal the mechanisms and hormones governing testicular descent. British Journal of Urology, 79, 99-112.

Clop A, Marcq F, Takeda H, Pirottin D, Tordoir X, Bibe B, Bouix J, Caiment F, Elsen JM, Eychenne F, Larzul C, Laville E, Meish F, Milenkovic D, Tobin J, Charlier C and Georges M. (2006) A mutation creating a potential illegitimate microRNA target site in the myostatin gene affects muscularity in sheep. Nature Genetics, 7, 813-818.

Cohen-Zinder M, Seroussi E, Larkin DM, Loor JJ, Everts-van der Wind A, Lee JH, Drackley JK, Band MR, Hernandez AG, Shani M, Lewin HA, Weller JI and Ron M. (2005) Identification of a missense mutation in the bovine ABCG2 gene with a major effect on the QTL on chromosome 6 affecting milk yield and composition in Holstein cattle. Genome Research, 7, 936-944.

Collignon J, Sockanathan S, Hacker A, Cohen-Tannoudji M, Norris D, Rastan S, Stevanovic M, Goodfellow PN and Lovell-Badge R. (1996) A comparison of the properties of Sox-3 with Sry and two related genes, Sox-1 and Sox-2. Development, 122, 509-520.

Colter DC, Piera-Velazquez S, Hawkins DF, Whitecavage MK, Jimenez SA and Stokes DG. (2005) Regulation of the human Sox9 promoter by the CCAAT-binding factor. Matrix Biology, 24, 185-197.

Daneau I, Pilon N, Boyer A, Behdjani R, Overbeek PA, Viger R, Lussier J and Silversides DW. (2002) The porcine $S R Y$ promoter is transactivated within a male genital ridge environment. Genesis, 33, 170-180.

Darvasi A. (1998) Experimental strategies for the genetic dissection of complex traits in animal models. Nature Genetics, 18, 19-24.

Denny P, Swift S, Connor F and Ashworth A. (1992) An SRY-related gene expressed during spermatogenesis in the mouse encodes a sequence-specific DNA-binding protein. EMBO Journal, 11, 3705-3712.

de Santa Barbara P, Bonneaud N, Boizet B, Desclozeaux M, Moniot B, Sudbeck P, Scherer G, Poulat F and Berta P. (1998) Direct interaction of SRY-related protein SOX9 and steroidogenic factor 1 regulates transcription of the human anti-Mullerian hormone gene. Molecular and Cellular Biology, 18, 6653-6665.

de Koning DJ, Dekkers JCM and Haley CS. (2003) Designs for QTL detection in livestock and their implications for MAS. The conference: Marker assisted selection, a fast track to increase genetic gain in plant and animal breeding? Session II, Marker assisted selection 
in animals, In Turin, Italy.

Drickamer LC, Rosenthal TL and Arthur RD. (1999) Factors affecting the number of teats in pigs. Journal of Reproduction and Fertility, 115, 97-100.

Drivdahl R, Haugk KH, Sprenger CC, Nelson PS, Tennant MK and Plymate SR. (2004) Suppression of growth and tumorigenicity in the prostate tumor cell line M12 by overexpression of the transcription factor SOX9. Oncogene, 23, 4584-4593.

Du FX, Mathialagan N, Dyer CJ, Grosz MD, Messer LA, Clutter AC, Wang T, Lohuis MM and Byatt JC. (2004) Mapping genes affecting scrotal hernia condition in domestic pigs. Journal of Animal Science, 82, Suppl.1, 453.

Farnir F, Grisart B, Coppieters W, Riquet J, Berzi P, Cambisano N, Karim L, Mni M, Moisio S, Simon P, Wagenaar D, Vilkki J and Georges M. (2002) Simultaneous mining of linkage and linkage disequilibrium to fine map quantitative trait loci in outbred half-sib pedigrees, revisiting the location chromosome 14. Genetics, 161, 275-287.

Fernandez A, Toro M, Rodriguez C and Silio L. (2004) Heterosis and epistasis for teat number and fluctuating asymmetry in crosses between Jiaxing and Iberian pigs. Heredity, 2, 22-27.

Fleischmajer R, Perlish JS, Burgeson RE, Shaikh-Bahai F and Timpl R. (1990) Type I and type III collagen interactions during fibrillogenesis. Annals of the New York Academy of Science, 580, 161-175.

Foster JW, Dominguez-Steglich MA, Guioli S, Kowk G, Weller PA, Stevanovic M, Weissenbach J, Mansour S, Young ID, Goodfellow PN, Brook JD and Schafer AJ. (1994) Campomelic dysplasia and autosomal sex reversal caused by mutations in an SRY-related gene. Nature, 372, 525-530.

Friedman DW, Boyd CD, Norton P, Greco RS, Boyarsi AH, Mackenzie JW and Deak SB. (1993) Increases in type III collagen expression in protein synthesis in patients with inguinal hernias. Annals of Surgery, 218, 754-760.

Geldermann H, Müller E, Moser G, Reiner G, Bartenschlager H, Cepica S, Stratil A, Kuryl J, Moran C, Davoli R and Brunsch C. (2003) Genome-wide linkage and QTL mapping in porcine F2 families generated from Pietrain, Meishan and Wild Boar crosses. Journal of Animal Breeding and Genetics, 120, 363-393.

Grindflek E, Moe M, Taubert H, Simianer H, Lien S and Moen T. (2006) Genome-wide linkage analysis of inguinal hernia in pigs using affected sib pairs. BMC Genetics, 7, 25.

Grisart B, Coppieters W, Farnir F, Karim L, Ford C, Berzi P, Cambisano N, Mni M, Reid S, 
Simon P, Spelman R, Georges M and Snell R. (2002) Positional candidate cloning of a QTL in dairy cattle: identification of a missense mutation in the bovine DGAT1 gene with major effect on milk yield and composition. Genome Research, 2, 222-231.

Haley CS, Knott SA and Elsen JM. (1994) Mapping quantitative trait loci in crosses between outbred lines using least squares. Genetics, 3, 1195-1207.

Harley VR, Clarkson MJ and Argentaro A. (2005) The molecular action and regulation of the testis-determining factors, SRY (sex-determining region on the $\mathrm{Y}$ chromosome) and SOX9 [SRY-related high-mobility group (HMG) box 9]. Endocrine Reviews, 24, 466-487.

Heyns CF, Human HJ, Werely CJ and DeKlerk DP. (1990) The glycosaminoglycans of the gubernaculum during testicular descent in the fetus. The Journal of Urology, 143, 612-617.

Hirooka H, de Koning DJ, Harlizius B, van Arendonk JA, Rattink AP, Groenen MA, Brascamp EW and Bovenhuis H. (2001) A whole-genome scan for quantitative trait loci affecting teat number in pigs. Journal of Animal Science, 9, 2320-2326.

Holl JW, Cassady JP, Pomp D and Johnson RK. (2004) A genome scan for quantitative trait loci and imprinted regions affecting reproduction in pigs. Journal of Animal Science, 82, 3421-3429.

Huang B, Wang S, Ning Y, Lamb AN and Bartley J. (1999) Autosomal XX sex reversal caused by duplication of SOX9. American Journal of Medical Genetics, 87, 349-353.

Huston R, Saperstein G, Schoneweis D and Leipold HW. (1978) Congenital defects in pigs. The Veterinary Bulletin, 48, 645-674.

Hutson JM, Chow CW and Ng WD. (1987) Persistent müllerian duct syndrome with transverse testicular descent. Pediatric Surgery International, 2, 242-246.

Hutson JM, Hasthorpe S and Heyns CF. (1997) Anatomical and functional aspects of testicular descent and cryptorchidism. Endocrine Reviews, 18, 259-280.

Hutson JM, Sasaki Y, Huynh J, Yong E and Ting A. (2004) The gubernaculum in testicular descent and cryptorchidism. The Turkish Journal of Pediatrics, 46, Suppl, 3-6.

Hutson JM and Hasthorpe S. (2005) Testicular descent and cryptorchidism: the state of the art in 2004. Journal of Pediatric Surgery, 40, 297-302.

Ivell R and Hartung S. (2003) The molecular basis of cryptorchidism. Molecular Human Reproduction, 9, 175-181.

Jansen PL, Mertens Pr P, Klinge U and Schumpelick V. (2004) The biology of hernia 
formation. Surgery, 1, 1-4.

Jay P, Berta P and Blache P. (2005) Expression of the carcinoembryonic antigen gene is inhibited by SOX9 in human colon carcinoma cells. Cancer Research, 65, 2193-2198.

Jenkinsn E, Mossa JB, Paceb JM and Bridgewatera Laura C. (2005) The new collagen gene COL27A1 contains SOX9-responsive enhancer elements. Matrix Biology, 3, 177-184.

Johnson ZB, Chewning JJ and Nugent III RA. (2003) Relationship between body length and number of nipples in swine. AAES Research Series, 509, 167-168.

Jungst SB and Kuhlers DL. (1983) Effect of teat number, teat abnormalities and underline length on litter sizes and weights at 21 and 42 days in swine. Journal of Animal Science, 4, 802-806.

Kamachi Y, Cheah KS and Kondoh H. (1999) Mechanism of regulatory target selection by the SOX high-mobility-group domain proteins as revealed by comparison of SOX1/2/3 and SOX9. Molecular and Cellular Biology, 19, 107-120.

Kanai Y and Koopman P. (1999) Structural and functional characterization of the mouse Sox9 promoter: implications for campomelic dysplasia. Human Molecular Genetics, 8, 691-696.

Kim JS, Jin DI, Lee JH, Son DS, Lee SH, Yi YJ and Park CS. (2005) Effects of teat number on litter size in gilts. Animal Reproduction Science, 90, 111-116.

King AH, Jiang Z, Gibson JP, Haley CS and Archibald AL. (2003) Mapping quantitative trait loci affecting female reproductive traits on porcine chromosome 8. Biology of Reproduction, 6, 2172-2179.

Klinge U, Zheng H, Si ZY, Schumpelick V, Bhardwaj R and Klosterhalfen B. (1999a) Altered collagen synthesis in fascia transversalis of patiens with inguinal hernia. Hernia, 4, 181-187.

Klinge U, Zheng H, Si ZY, Schumpelick V, Bhardwaj R and Klosterhalfen B. (1999b) Synthesis of type I and III collagen, expression of fibronectin and matrix metalloproteinases-1 and -13 in hernial sac of patients with inguinal hernia. International Journal of Surgical Investigation, 1, 219-227.

Klinge U, Zheng H, Si ZY, Schumpelick V, Bhardwaj R and Klosterhalfen B. (1999c) Expression of the extracellular matrix proteins collagen I, collagen III and fibronectin and matrix metalloproteinase- 1 and -13 in the skin of patients with inguinal hernia. European Surgical Research, 31, 480-490.

Knap PW. (1986) Congenital defects inheritance of AI boars: genetic parameters and breeding 
value estimation procedures. Livestock Production Science, 15, 337-352.

Knorr C, Peters U, Henne H, Woerner R, Harlizius B and Brenig B. (2002a) A total genome scan and analysis of candidate genes for scrotal hernia in pigs. Abstract presented at the ISAG 2002 meeting, Göttingen, Germany.

Knorr C, Kollers S, Fries R and Brenig B. (2002b) Assignment of the CALCA/alpha-CGRP gene (CALCA) to porcine chromosome SSC2p13-->p11 by fluorescence in situ hybridization and by analysis of somatic cell and radiation hybrid panels. Cytogenetic and Genome Research, 97, 140.

Knorr C, Täubert H, Peters U and Brenig B. (2004) Characterization of two SNPs (Single-Nucleotide Polymorphisms) in the porcine INSL3 gene and their exclusion as a common genetic basis of Hernia Inguinalis in Pigs. Biochemical Genetics, 42, 11-19.

Knorr C, Bornemann-Kolatzki K and Brenig B. (2006) Genome-wide scan for porcine rupture identifies association with several chromosomal regions. In: Plant and Animal Genome XIV; San Diego.

Knott SA, Marklund L, Haley CS andersson K, Davies W, Ellegren H, Fredholm M, Hansson I, Hoyheim B, Lundstrom K, Moller M and Andersson L. (1998) Multiple marker mapping of quantitative trait loci in a cross between outbred wild boar and large white pigs. Genetics, 149, 1069-1080.

Koskimies P, Levallet J, Sipila P, Huhtaniemi I and Poutanen M. (2002) Murine relaxin-like factor promoter: functional characterization and regulation by transcription factors steroidogenic factor 1 and DAX-1. Endocrinology, 143, 909-919.

Kubota Y, Nef S, Farmer PJ, Temelcos C, Parada LF and Hutson JM. (2001) Leydig insulin-like hormone and gubernacular development and testicular descent. The Journal of Urology, 165, 1673-1675.

Kubota Y, Temelcos C, Bathgate RA, Smith KJ, Scott D, Zhao C and Hutson JM. (2002) The role of Insulin 3, testosterone, MIS and relaxin in rat gubernacular growth. Molecular Human Reproduction, 8, 900-905.

Lahbib-Mansais Y, Barbosa A, Yerle M, Parma P, Milan D, Pailhoux E, Gellin J and Cotinot C. (1997) Mapping in pig of genes involved in sexual differentiation: AMH, WT1, FTZF1, SOX2, SOX9, AHC and placental and embryonic CYP19. Cytogenetics and Cell Genetics, 76, 109-114.

Lefebvre V, Huang W, Harley VR, Goodfellow PN and de Crombrugghe B. (1997) SOX9 is a potent activator of the chondrocytespecific enhancer of the pro alpha1(II) collagen gene. 
Molecular and Cellular Biology, 17, 2336-2346.

Lichtenstein IL, Shulman AG and Amid PK. (1993) The cause, prevention and treatment of recurrent groin hernia. The Surgical Clinics of North America, 73, 529-544.

Lingaas F and Ronningen K. (1991) Epidemiological and genetical studies in Norwegian pig herds. II. Overall disease incidence and seasonal variation. Acta Veterinaria Scandinavica, 32, 89-96.

Lynch M and Walsh B. (1998) Genetics and analysis of quantitative traits. Sinauer associates Inc, Sunderland.

Magee WT. (1951) Inheritance of scrotal hernia in swine. Journal of Animal Science, 10, 516-522.

Marinkovic S and Bukarica S. (2003) Umbilical hernia in children. Medicinski Pregled, 56, 291-294.

Mehar SK, Peter CT, Imke T and Herman WR. (2004) Quantitative trait loci mapping in dairy cattle: review and meta-analysis. Genetics Selection Evolution, 36, 163-190.

Mertin S, McDowall SG and Harley V. (1999) The DNA-binding specificity of SOX9 and other SOX proteins. Nucleic Acids Research, 5, 1359-1364.

Mikami H and Fredeen HT. (1979) A genetic study of cryptorchidism and scrotal hernia in pigs. Canadian Journal of Genetics and Cytology, 21, 9-19.

Morishita M, Kishino T, Furukawa K, Yonekura A, Miyazaki Y, Kanematsu T, Yamashita S and Tsukazaki T. (2001) A 30-base-pair element in the first intron of SOX9 acts as an enhancer in ATDC5. Biochemical and Biophysical Research Communications, 288, 347-355.

Morris-Stiff G, Coles G, Moore R, Jurewicz A and Lord R. (1997) Abdominal wall hernia in autosomal dominant polycystic kidney disease. The British Journal of Surgery, 84, 615-617.

Nef S and Parada L. (1999) Cryptorchidism in mice mutant from INSL3. Nature Genetics, 22, 295-299.

Ohe K, Lalli E and Sassone-Corsi P. (2002) A direct role of SRY and SOX proteins in pre-mRNA splicing. Proceedings of the National Academy of Sciences USA, 99, 1146-1151.

Pans A, Pierard GE, Albert A and Desaive C. (1997) Adult groin hernias: new insight into their biomechanical characteristics. European Journal of Clinical Investigation, 27, 863-868. 
Pans A, Albert A, Lapiere CM and Nusgens B. (2001) Biochemical study of collagen in adult groin hernias. Journal of Surgical Research, 95, 107-113.

Parma P, Pailhoux E and Cotinot C. (1999) Reverse transcription-polymerase chain reaction analysis of genes involved in gonadal differentiation in pigs. Biology of Reproduction, 61, 741-748.

Peacock EE and Madden IW. (1974) Studies on the biology and treatment of recurrent inguinal hernia: II. morphological changes. Annals of Surgery, 179, 567-571.

Perez-Enciso M and Varona L. (2000) Quantitative trait loci mapping in F(2) crosses between outbred lines. Genetics, 1, 391-405.

Perez-Enciso M, Clop A, Folch JM, Sanchez A, Oliver MA, Ovilo C, Barragan C, Varona L and Noguera JL. (2002) Exploring alternative models for sex-linked quantitative trait loci in outbred populations: application to an iberian x landrace pig intercross. Genetics, 4, 1625-1632.

Plastow G, Sasaki S, Yu TP, Deeb N, Prall G, Siggens K and Wilson E. (2003) Practical Application of DNA Markers for Genetic Improvement. NSIF, 28. Iowa, USA.

Pumfrey RA, Johnson RK, Cunningham PJ and Zimmerman DR. (1980) Inheritance of teat number and its relationship to maternal traits in swine. Journal of Animal Science, 6, 1057-1060.

Qin Y and Bishop CE. (2005) Sox9 is sufficient for functional testis development producing fertile male mice in the absence of Sry. Human Molecular Genetics, 14, 1221-1229.

Reed JC. (2000) Mechanisms of apoptosis. American Journal of Pathology, 157, 1415-1430.

Riquet J, Coppieters W, Cambisano N, Arranz JJ, Berzi P, Davis SK, Grisart B, Farnir F, Karim L, Mni M, Simon P, Taylor JF, Vanmanshoven P, Wagenaar D, Womack JE and Georges M. (1999) Fine-mapping of quantitative trait loci by identity by descent in outbred populations: Application to milk production in dairy cattle. Proceedings of the National Academy of Sciences USA, 96, 9252-9257.

Robert K and George CE. (2004) Anatomy, Histology and Cell Biology. McGraw-Hill Medical.

Rodrigues CJ, Yoo JH and Rodrigues Jr AJ. (2006) Elastin (ELN) gene point mutation in patients with inguinal hernia. Genetics and Molecular Biology, 29, 1, 45-46.

Rodrigues Jr AJ, Rodrigues CJ, Cunha ACP and Yoo JH. (2002) Quantitative analysis of collagen and elastic fibers in transversalis fascia in direct and indirect inguinal hernia. Revista do Hospital das Clínicas, 57, 265-270. 
Rodriguez C, Tomas A, Alves E, Ramirez O, Arque M, Munoz G, Barragan C, Varona L, Silio L, Amills $\mathrm{M}$ and Noguera JL. (2005) QTL mapping for teat number in an Iberian-by-Meishan pig intercross. Animal Genetics, 6, 490-496.

Rohrer GA. (2000) Identification of quantitative trait loci affecting birth characters and accumulation of backfat and weight in a Meishan-White Composite resource population. Journal of Animal Science, 10, 2547-2553.

Ron M, Tager-Cohen I, Feldmesser E, Ezra E, Kalay D, Roe B, Seroussi E and Weller JI. (2004) Bovine umbilical hernia maps to the centromeric end of Bos taurus autosome 8. Animal Genetics, 35, 431-437.

Rosch R, Klinge U, Si Z, Junge K, Klosterhalfen B and Schumpelick V. (2002) A role for the collagen I/III and MMP-1/-13 genes in primary inguinal hernia? BMC Medical Genetics, 3,2 .

Rothschild MF and Ruvinsky A. (1998) The Genetic of the Pig. CAB International, Oxon, UK.

Rothschild MF. (2003) Advances in pig genomics and functional gene discovery. Comparative and Functional Genomics, 4, 266-270.

Sanchez MP, Bidanel JP, Zhang S, Naveau J, Burlot T and Le Roy P. (2003) Likelihood and Bayesian analyses reveal major genes affecting body composition, carcass, meat quality and the number of false teats in a Chinese European pig line. Genetics Selection Evolution, 4, 385-402.

Sato S, Atsuji K, Saito N, Okitsu M, Sato S, Komatsuda A, Mitsuhashi T, Nirasawa K, Hayashi T, Sugimoto Y and Kobayashi E. (2006) Identification of quantitative trait loci affecting corpora lutea and number of teats in a Meishan x Duroc F2 resource population. Journal of Animal Science, 11, 2895-2901.

Shen JH and Ingraham HA. (2002) Regulation of the orphan nuclear receptor steroidogenic factor 1 by Sox proteins. Molecular Endocrinology, 16, 529-540.

Smith KJ, Wade JD, Claasz AA, Otvos L Jr, Temelcos C, Kubota Y, Hutson JM, Tregear GW and Bathgate RA. (2001) Chemical synthesis and biological activity of rat insl3. Journal of Peptide Science, 7, 495-501.

Sock E, Pagon RA, Keymolen K, Lissens W, Wegner M and Scherer G. (2003) Loss of DNA-dependent dimerization of the transcription factor SOX9 as a cause for campomelic dysplasia. Human Molecular Genetics, 12, 1439-1447.

Spokony RF, Aoki Y, Saint-Germain N, Magner-Fink E and Saint-Jeannet JP. (2002) The 
transcription factor Sox9 is required for cranial neural crest development in Xenopus. Development, 129, 421-432.

Stolt CC, Lommes P, Sock E, Chaboissier MC, Schedl A and Wegner M. (2003) The Sox9 transcription factor determines glial fate choice in the developing spinal cord. Genes and Development, 17, 1677-1689.

Sudbeck P, Schmitz ML, Baeuerle PA and Scherer G. (1996) Sex reversal by loss of the C-terminal transactivation domain of human SOX9. Nature Genetics, 13, 230-232.

Tanyel FC, Dagdeviren A, Müftüoglu S, Gürsoy MH, Yörüker S and Büyükpamukçu N. (1999) Inguinal hernia revisited through comparative evaluation of peritoneum, processus vaginalis and sacs obtained from children with hernia, hydrocele and undescended testis. Journal of Pediatric Surgery, 34, 552-555.

Tanyel FC. (2000) A reevaluation of the mechanism of testicular descent: reasons for failed descent or ascent. Journal of Pediatric Surgery, 35, 1147-1149.

Tanyel FC, Erdem S, Büyükpamukçu N and Tan E. (2002) Smooth muscle in incomplete obliterations of processus vaginalis lacks apoptotic nuclei. Urologia Internationalis, 69, $42-45$.

Tanyel FC, Ulusu NN, Tezcan EF and Buyukpamukcu N. (2003) Total calcium content of sacs associated with inguinal hernia, hydrocele or undescended testis reflects differences dictated by programmed cell death. Urologia Internationalis, 70, 211-215.

Tanyel FC and Okur HD. (2004) Autonomic nervous system appears to play a role in obliteration of processus vaginalis. Hernia, 8, 149-154.

Tanyel FC. (2004a) Obliteration of processus vaginalis: aberrations in the regulatory mechanism result in an inguinal hernia, hydrocele or undescended testis. The Turkish Journal of Pediatrics, Suppl, 18-27.

Tanyel FC. (2004b) The descent of testis and reason for failed descent. The Turkish Journal of Pediatrics, Suppl, 7-17.

Thaller G, Dempfle L and Hoeschele I. (1996) Maximum likelihood analysis of rare binary traits under different modes of inheritance. Genetics, 143, 819-829.

Tomiyama H, Hutson JM, Truong A and Agoulnik AI. (2003) Transabdominal testicular descent is disrupted in mice with deletion of insulin-like factor 3 receptor. Journal of Pediatric Surgery, 38, 1793-1798.

Tommerup N, Schempp W, Meinecke P, Pedersen S, Bolund L, Brandt C, Goodpasture C, Guldberg P, Held KR, Reinwein H, Saugstad OD, Scherer G, Skjeldal O, Toder R, 
Westvik J, van der Hagen CB and Wolf U. (1993) Assignment of an autosomal sex reversal locus (SRA1) and campomelic dysplasia (CMPDI) to 17q24.3-q25.1. Nature Genetics, 4, 170-174.

Toro MA, Dobao MT, Rodrigánez J and Silió L. (1986) Heritability of a canalized trait: teat number in Iberian pigs. Genetics Selection Evolution, 18, 173-184.

Truong A, Bogatcheva NV, Schelling C, Dolf G and Agoulnik AI. (2003) Isolation and expression analysis of the canine insulin-like factor 3 gene. Biology of Reproduction, 69 , 1658-1664.

Uden A and Lindhagen T. (1988) Inguinal herniation in patients with congenital dislocation of the hip: a sign of general connective tissue disorder. Acta Orthop Scand, 59, 667-668.

Van der Schoot P and Elger W. (1992) Androgen-induced prevention of the outgrowth of cranial gonadal suspensory ligaments in fetal rats. Journal of Andrology, 3,534-42.

Van Laere AS, Nguyen M, Braunschweig M, Nezer C, Collette C, Moreau L, Archibald AL, Haley CS, Buys N, Tally M, Andersson G, Georges M and Andersson L. (2003) A regulatory mutation in IGF2 causes a major QTL effect on muscle growth in the pig. Nature, 425, 832-836.

Van Wessem KJ, Simons MP, Plaisier PW and Lange JF. (2003) The etiology of indirect inguinal hernias: congenital and/or acquired? Hernia, 7, 76-79.

Vidal VP, Chaboissier MC, de Rooij DG and Schedl A. (2001) Sox9 induces testis development in XX transgenic mice. Nature Genetics, 28, 216-217.

Vogt DW and Ellersieck MR. (1990) Heritability of susceptibility to scrotal herniation in swine. American Journal of Veterinary Research, 51, 1501-1503.

Wada Y, Akita T, Awata T, Furukawa T, Sugai N, Inage Y, Ishii K, Ito Y, Kobayashi E, Kusumoto H, Matsumoto T, Mikawa S, Miyake M, Murase A, Shimanuki S, Sugiyama T, Uchida Y, Yanai S and Yasue H. (2000) Quantitative trait loci (QTL) analysis in a Meishan x Göttingen cross population. Animal Genetics, 6, 376-384.

Wagner T, Wirth J, Meyer J, Zabel B, Held M, Zimmer J, Pasantes J, Bricarelli FD, Keutel J, Hustert E, Wolf U, Tommerup N, Schempp W and Scherer G. (1994) Autosomal sex reversal and campomelic dysplasia are caused by mutations in and around the SRY-related gene SOX9. Cell, 79, 1111-1120.

Wang X, Le Roy I, Nicodeme E, Li R, Wagner R, Petros C, Churchill GA, Harris S, Darvasi A, Kirilovsky J, Roubertoux PL and Paigen B. (2003) HDL Cholesterol Quantitative Trait Loci Using Advanced Intercross Lines for High-Resolution Mapping of HDL 
Cholesterol Quantitative Trait Loci. Genome Research, 13, 1654-1664.

Wiedemann H, Chung E, Fujii T, Miller EJ and Kuhn K. (1975) Comparative electronmicroscope studies on type-III and type-I collagens. European Journal of Biochemistry, 51, 363-368.

Womack JE. (2005) Advances in livestock genomics: opening the barn door. Genome Research, 15, 1699-1705.

Wrathall AE. (1988) The boar and congenital problems. Pig Veterinary Society Proceeding, 21, 116-143.

Zalzali H, Jay P, Yaghi C and Blache P. (2006) SOX9 is a transcriptional activator of the human tumor suppresson CEACAM1. Proceedings of the American Association for Cancer Research, 47, Abstract 41.

Zimmermann S, Schwarzler A, Buth S, Engel W and Adham IM. (1998) Transcription of the Leydig insulin-like gene is mediated by steroidogenic factor-1. Molecular Endocrinology, 12, 706-713.

Zimmermann S, Steding G, Emmen JM, Brinkmann AO, Nayernia K, Holstein AF, Engel W and Adham IM. (1999) Targeted disruption of the INSL3 gene causes bilateral cryptorchidism. Molecular Endocrinology, 13, 681-91. 


\section{Acknowledgements}

It is my proud privilege to thank all the people who meticulously supervised me and kindly help me during my $\mathrm{PhD}$ study at the Institute of Veterinary Medicine (IVM) in the Faculty of Agricultural Sciences, Georg-August-University of Göttingen.

I would like to deliver my deepest sense of gratitude and indebtedness to Prof. Dr. Dr. Bertram Brenig, an excellent supervisor and Head of IVM, for his greatest guidance, constructive suggestion and continuous support that allowed me to have the great opportunity to work in the IVM and conduct my doctorate successfully. I am highly thankful to my co-supervisor Prof. Dr. Christoph Knorr for his affectionate counselling, splendid pilot to the fascinating field of molecular genetics and kindest help whenever I needed during all these years. I also want to deliver my sincere thanks to my co-supervisor Prof. Dr. Lusheng Huang (Jiangxi Agricultural University (JXAU), China) for his elaborate organization that made me fulfilled part work of the thesis in JXAU, and his valuable direction and encouragement.

I specially want to thank Prof. Dr. Henner Simianer and Prof. Dr. Dr. Matthias Gauly for kindly being my co-examiner.

I owe sincere appreciations to my good friend Dr. Bernhard Baumgartner for his kind help on expression work, thoughtful comments and enthusiasms always available to answer my questions and bring fun to my life in Göttingen. I also want to heartily thank Miss Julia Beck for her great help especially at the beginning of my study, for her excellent FISH analysis and beneficial guidance on computer technology. I would like to express my thanks to Viola Raupach and Susen Lattermann for their technical assistance. Many thanks are also due to Dr. Alexandra Baumgartner, Dr. Ekkehard Schütz and other graduate students Christian Beuermann, Monique Germerodt, Rifat Morina, Claudia Floren and other colleagues Sara Henneke and Stefan Balzer for their assistance during my research. Moreover, I also want to express my sincere thanks to Miss Joana Luis Armada Bras for her kind help on EMSA and expression work.

I am very grateful to my Chinese colleagues at JXAU Dr. Jun Ren, Mrs. Jun Gao and Mr. Yuanmei Guo for their help on the part work of this thesis in China.

Finally, I would like to devote my deep thanks to my large family for their eternal support and immense encouragement. I would greatly appreciate my fiancée Shuting Zhu for her unfailing soulful love that gave me the constant inspiration to fulfill my PhD study. 


\section{Curriculum Vitae}

$\begin{array}{ll}\text { Family Name: } & \text { Ding } \\ \text { First Name: } & \text { Nengshui } \\ \text { Date of Birth: } & \text { 22 July } 1975 \\ \text { Place of Birth: } & \text { Jiangxi, P. R. China } \\ \text { Marital Status: } & \text { Unmarried } \\ \text { Parents: } & \text { Zhulin Ding and Xianglian Wu } \\ \text { Nationality: } & \text { P. R. China }\end{array}$

\section{Education and Professional Experiences}

July 2004 -

July 2000 - June 2004

September 1997 - July 2000

September 1993 - July 1997
Postgraduate student for PhD degree

Major: Molecular Genetics in livestock

Institute of Veterinary Medicine,

Georg-August-University Göttingen, Germany

Lecturer in Animal Genetics and Breeding

Faculty of Animal Science and Veterinary Technology,

Jiangxi Agricultural University, Nanchang, P. R. China

Postgraduate student for Master of Science degree

Major: Animal Genetics and Breeding

Faculty of Animal Science and Veterinary Technology, Jiangxi Agricultural University, Nanchang, P. R. China

Undergraduate student for Bachelor of Science degree Major: Animal Science and Technology

Faculty of Animal Science and Veterinary Technology, Jiangxi Agricultural University, Nanchang, P. R. China 